\title{
DELITOS CONTRA LOS DERECHOS DE LOS TRABAJADORES: VEINTICINCO AÑOS DE POLÍTICA LEGISLATIVA ERRÁTICA
}

\author{
Juan María Terradillos Basoco*
}

Resumen: El Código Penal español de 1995 (Código Penal de la democracia) introdujo un innovador Título XV, dedicado a los delitos contra los derechos de los trabajadores. Veinticinco años más tarde, estos delitos han registrado numerosas reformas, asistemáticas, de escaso rigor técnico, y, sobre todo, ajenas al objetivo de tutela de los derechos propios del colectivo de trabajadores. Al margen del Título $\mathrm{XV}$, la reforma más relevante es la relativa a los delitos contra el sistema de SS, que castigan las conductas de trabajo en negro con un excesivo y discriminatorio rigor penal.

Palabras clave: Acoso laboral, acoso sexual, discriminación, defraudación, inmigración. libertad sindical, trabajo en negro, trabajo forzoso, trata de seres humanos, vida y salud de los trabajadores.

Recibido: abril 2020. Aceptado: julio 2020

* Profesor Emérito. Catedrático de Derecho Penal. ORCID: 0000-00025361-3009

Facultad de Derecho de la Universidad de Cádiz. Dirección Avda. de la Universidad, 4. 11406. Jerez. Email: jtebas58@gmail.com 
Abstract: The 1995 Spanish Criminal Code (known as "Democracy Criminal Code") introduced an innovative Title XV on Crimes Against Workers' Rights: Twenty-Five Years of Erratic Legislative Policy later, these crimes have undergone many amendments with poor systematic and technical accuracy that had nothing to do with the protection of workers' rights. Apart from Title XV, the most important amendment is the one related to crimes against the Social Welfare system, that punishes undeclared work behaviors in an undue and discriminating way.

Keywords: Work harassment, sexual harassment, discrimination, fraud, immigration, union freedom, undeclared work, forced labor, human trafficking, worker's health and life.

\section{Planteamiento}

La introducción, por parte del Código Penal (CP) de 1995, del Título XV de su Libro II supuso dar respaldo normativo a una realidad que, los códigos penales de la dictadura habían escamoteado: los derechos de los trabajadores constituyen un bien jurídico susceptible y merecedor de tutela penal autónoma, que trasciende los intereses puramente económicos implicados en la relación laboral, cuya titularidad colectiva determina su carácter indisponible y decide la respuesta a los problemas concursales planteados cuando la conducta delictiva afecta, además, a bienes jurídicos de titularidad individual.

El legislador, en palabras del Tribunal Supremo (TS), partió "de la existencia de una determinada clase social: los trabajadores por cuenta ajena que intervienen en el mercado de trabajo en condiciones de inferioridad respecto de los empleadores", ya que "el contrato de trabajo descansa sobre una situación asimétrica, porque el empleadorlempresario se encuentra en una situación más fuerte que el trabajadorlempleado". En consecuencia, el CP 1995 conformó "un objeto de tutela unitario, sin perjuicio de que concretos tipos delictivos 
concedan una especifica protección inmediata a alguno de esos derechos" 1 .

Con este fundamento, y a instancias de una enmienda al proyecto de CP de 1995 presentada por el grupo parlamentario de Izquierda Unida, se redactó un Título autónomo, que incluyó los artículos 311 a $318^{2}$.

Las sucesivas reformas legales que han afectado a estos preceptos, así como a otros dispersos en el articulado del Código que también castigan comportamientos enmarcados en la relación laboral, no se corresponden con una estrategia político-criminal nítida en sus objetivos, principios o medios. Con independencia de lo acertado de algunas de las reformas a examen, es lo cierto que, una vez transcurridos veinticinco años, el marco general está constituido por una yuxtaposición amalgamada de delitos y penas de difícil manejo por los operadores jurídicos, que no pueden recurrir, en la interpretación, a criterios de teleología o funcionalidad, inidentificables en itinerarios legiferantes que se han movido sin rumbo, que han sido imprevisibles o que cambiaron con frecuencia. Que, en síntesis, reflejan una política legislativa errática, en la que, no obstante, son identificables dos claras directrices, por lo demás político-criminalmente complementarias, que configuran el Derecho Penal del Trabajo del siglo XXI: "por un lado, se mantiene su fuerza represiva en el ámbito de las relaciones colectivas de trabajo... al tiempo que, por otro lado, ha quedado desnaturalizado en las relaciones individuales y de SS, mediante las reformas laborales que han vaciado de contenido [su] carácter protector"’3.

1 STS, 2a ${ }^{\mathrm{a}}$ 5.04.2017, Fundamentos de Derecho. Tercero (Ecli: ES:TS:2017:1303). Reproducida en este punto por STS, 2a , 28.09.2017, Fundamentos de Derecho. Quinto (Ecli: ES:TS:2017:3389).

2 LÓPEZ GARRIDO, D., y GARCÍA ARÁN, M., El Código Penal de 1995 y la voluntad del legislador, Eurojuris, Madrid, 1996, p. 153.

3 DOLZ LAGO, M.J., “¿Existió alguna vez un verdadero Derecho penal del trabajo?", en DE LA CUESTA AGUADO, P.M., et alii (coord.), 
Las líneas que siguen no pretenden un examen pormenorizado de los artículos del CP dedicados, bajo esa rúbrica o bajo otras, a los delitos contra los derechos de los trabajadores, sino a las reformas sufridas.

\section{Integridad moral: acoso laboral}

El art. 173.1 CP, en su párrafo segundo, castiga con prisión de seis meses a dos años a los que "en el ámbito de cualquier relación laboral o funcionarial y prevaliéndose de su relación de superioridad, realicen contra otro de forma reiterada actos hostiles o humillantes que, sin llegar a constituir trato degradante, supongan grave acoso contra la víctima".

Este párrafo, obra de la Ley Orgánica (LO) 5/2010, abordó, tal como explica la Exposición de Motivos (EM). XI, la criminalización, tanto en los ámbitos jurídico-privados como en los públicos, del acoso laboral, "entendiendo por tal el hostigamiento psicológico u hostil en el marco de cualquier actividad laboral o funcionarial que humille al que lo sufre, imponiendo situaciones de grave ofensa a la dignidad" .

En definitiva, el legislador de 2010 pretendió incorporar al CP exigencias comunitarias posteriores a 1995 y plasmadas inicialmente en la Directiva 2000/78/CE, y más tarde, en la Resolución del Parlamento Europeo sobre el acoso moral o mobbing en el lugar de trabajo 2001/2339, y en las Directivas 2004/113/CE y 2006/54/CE.

En Derecho interno, el Estatuto de los Trabajadores (ET), reformado por la $L O 3 / 2007$, ya había proclamado el derecho de los trabajadores a la "protección frente al acoso" (art. 4.2.e) y la Ley de Infracciones y Sanciones en el Orden Social (LISOS), del año 2000, en su art. 8.13 y 13 bis, reformado por Ley 62/2003, consideraba infracción muy grave

Liber amicorum. Estudios jurídicos en Homenaje al Prof. Dr. Dr. H.c. Juan M M $^{\mathrm{a}}$ Terradillos Basoco, Tirant lo Blanch, Valencia, 2018, p. 977. 
tanto "el acoso sexual..." como "el acoso por razón de origen racial o étnico... ..., cuando se produzcan dentro del ámbito a que alcanzan las facultades de dirección empresarial, cualquiera que sea el sujeto activo del mismo, siempre que, conocido por el empresario, éste no hubiera adoptado las medidas necesarias para impedirlo".

La descripción legal de la conducta delictiva no da cobijo al complejo catálogo de manifestaciones de acoso recogidas en la normativa extra-penal, nacional o comunitaria, conocidas doctrinalmente como mobbing ${ }^{4}$, burnout, etc., ni coincide con el hostigamiento psicológico u hostil que, en la tautológica fórmula de la $E M$, humilla a la víctima u ofende su dignidad.

El bien jurídico -la integridad moral, a tenor de la rúbrica del Título VII- enraiza en los artículos 1, 10 o 15 de la Constitución (CE) y se vincula inmediatamente a la dignidad de la persona, concepto que, sin embargo, no ayuda, en su amplitud y trascendencia, a la concreción del objeto de tutela penal. De ahí que la jurisprudencia prefiera asociar la integridad moral a la inviolabilidad de la personalidad humana, es decir, "al derecho a ser tratado como persona y no como $\operatorname{cosa}{ }^{\prime \prime}$. La identificación de un bien jurídico definido habría resultado más sencilla si el legislador hubiera optado por la ubicación sistemática de esta figura en el marco de los delitos contra los derechos de los trabajadores, aunque no fuera más que para evitar la incoherencia de proteger en el Título XV la vida, la salud u otros de sus derechos, y no la integridad moral amenazada por un acoso específicamente "laboral"'.

4 STS, 2a 21.12.2018, Fundamentos de Derecho. Tercero (Ecli: ES:TS:2018:4360)

5 STS, 2a 26.09.2016, Fundamentos de Derecho. Cuarto (Ecli: ES:TS:2016:4088)

6 POMARES CINTAS, E., El Derecho Penal ante la explotación laboral y otras formas de violencia en el trabajo, Tirant lo Blanch, Valencia, 2013, p. 216. 
El acoso laboral requiere, en su límite mínimo, la realización, desde la superioridad, de actos hostiles o humillantes reiterados, aunque no el "terror" ni, mucho menos, el "trato degradante" , que lejos de ser una manifestación del delito de acoso, constituye por expresa decisión legal, otro delito. Pero lo degradante, en el Diccionario de la Lengua Española (DLE) no es sino lo que humilla, rebaja o envilece, lo que, en una ineludible interpretación gramatical, sugiere zonas secantes con el acoso. Con lo que la confusión permanece. Y no la solventa la interpretación jurisprudencial que ofrece la STS de 26.09.2016, que, apelando a jurisprudencia anterior, entiende por trato degradante el que provoca "la sensación de humillación y de cosificación que tiene la víctima porque resulta agredida en lo que es más esencial del individuo: su dignidad de ser humano merecedor de respeto por su condición humana"s. En efecto, esa sensación de humillación que sufre la víctima puede estar presente también en el delito de acoso ("actos humillantes"), como lo está la agresión ("actos hostiles") a la dignidad, sin que la gravedad del ataque pueda constituirse en criterio válido de delimitación, por cuanto la ley la exige en ambos delitos.

No queda pues, para delimitar los respectivos ámbitos de tipicidad -al margen de la relación de superioridad y la reiteración propias del acoso, no necesarias pero sí posibles en el trato degradante-, sino volver a la consideración comparativa de los respectivos resultados: los actos hostiles o humillantes comportarían molestias o requerimientos que redundan en presión psicológica (resultado) sobre el acosado, pero no hasta el punto de menoscabar su dignidad o integridad moral, que sería el resultado del delito de trato degradante.

7 Como afirma la STS, 2a 2 21.12.2018, Fundamentos de Derecho. Tercero (Ecli: ES:TS:2018:4360), aunque en párrafo subsiguiente, reiterando la fórmula legal, señala como uno de los elementos del delito, los actos hostiles o humillantes, "sin llegar a constituir delito de trato degradante."

8 STS, 2a , 26.09.2016, Fundamentos de Derecho. Cuarto (ECLI: ES:TS:2016:4088) 
El acoso se consumaría cuando, concurriendo los demás elementos del tipo, pudiera afirmarse que la integridad de la víctima ha sido objetivamente atacada, pero no disminuida.

Otros elementos de la fórmula legal de 2010 requieren también un esfuerzo interpretativo que, en aplicación de técnicas legislativas más acertadas, podría haberse ahorrado.

La exigencia expresa de que en el acoso laboral el autor se prevalga de "su relación de superioridad" puede llevar a negar la tipicidad en situaciones de superioridad puramente fáctica. Una interpretación en este sentido debe ser rechazada, pero vendría avalada por la lectura conjunta de los artículos 173.1, párrafo segundo, y 184: aquel fija como marco "cualquier relación laboral o funcionarial" en la que el autor se prevale de su "relación de superioridad"; en este, se distingue entre relación laboral como marco (art. 184.1) y prevalimiento de una "situación de superioridad" como medio (art. 184.2), lo que facilita entender típicas conductas de acoso con prevalimiento de una contingencia y no de una estructura.

El art. 177 contiene una regla concursal expresa, aplicable a los delitos a examen: "Si... además del atentado a la integridad moral, se produjere lesión o daño a la vida, integridad física, salud, libertad sexual o bienes de la víctima o de un tercero, se castigarán los hechos separadamente con la pena que les corresponda por los delitos cometidos, excepto cuando aquél ya se halle especialmente castigado por la ley".

Tampoco la previsión legal aclara definitivamente todas las dudas posibles. Porque contempla dos situaciones de concurso infraccional distintas. En efecto, los ataques a la integridad moral pueden tener consecuencias lesivas para la salud de la víctima ("el caso de que un solo hecho constituya dos o más delitos", art. 77.1 CP). Pero también las lesiones o daños pueden utilizarse como medio hostil o humillante para acosarla ("cuando uno de ellos sea medio necesario para cometer el otro", art. 77.1). En cada caso procedería aplicar 
las respectivas reglas de los artículos 77.2 y 77.3. Pero el legislador, sin haber expuesto las razones para excepcionar la aplicación de estas reglas generales, ha optado por castigar "separadamente" los hechos, lo que parece remitir a un concurso real de delitos del art. 73.

\section{Libertad sexual: acoso sexual en el trabajo}

El art. 184, en su versión original de 1995, castigaba la solicitud de favores sexuales por parte de quien se prevale de "una situación de superioridad laboral, docente o análoga, con el anuncio expreso o tácito de causar a la víctima un mal relacionado con las legítimas expectativas que pueda tener en el ámbito de dicha relación”. Las penas eran de arresto de doce a veinticuatro fines de semana o multa de seis a doce meses.

El elemento nuclear del tipo era, pues, "solicitar favores de naturaleza sexual". La trasnochada fórmula remitía, en el Diccionario de la Academia -hoy DLE - a buscar con cuidado, pedir respetuosamente o requerir de amores y no puede, por tanto, ser interpretada literalmente; por ejemplo, porque es incompatible con la amenaza o el prevalimiento del actual art. $184.2^{9}$. No obstante, es fórmula que ha permanecido inalterada en las ulteriores reformas.

Con la más importante de ellas, la operada por $L O$ 11/1999, el apartado 1 del art. 184 pasó a castigar, con arresto de seis a doce fines de semana o multa de tres a seis meses, el acoso sexual horizontal, "en el ámbito de una relación laboral, docente o de prestación de servicios", que provocare a la víctima una situación jobjetiva y gravemente intimidatoria, hostil o humillante". Y el nuevo apartado 2 castigó el acoso vertical con prevalimiento, del anterior art. 184, con las mismas penas que lo había castigado este. El apartado 3 agravó

9 TERRADILlOS BASOCO, J.M., y BOZA MARTÍNEZ, D., El Derecho penal aplicable a las relaciones laborales. Lecciones, Bomarzo, Albacete, 2017, p. 184. 
las penas-"arresto de doce a veinticuatro fines de semana o multa de seis a doce meses en los supuestos previstos en el apartado 1, y de prisión de seis meses a un año en los supuestos previstos en el apartado 2 del presente artículo"- cuando la víctima fuere especialmente vulnerable, por razón de su edad, enfermedad o situación.

El texto vigente, fruto de la $L O 15 / 2003$, eleva, una vez más, las penas del acoso sexual horizontal a prisión de tres a cinco meses o multa de seis a diez meses; las del acoso vertical con prevalimiento, a prisión de cinco a siete meses o multa de diez a catorce meses; y las de acoso sobre víctima especialmente vulnerable, a prisión de cinco a siete meses o multa de diez a catorce meses en los supuestos del apartado 1 ; se mantuvo la pena del apartado 2.

La fórmula tipificadora a la que recurrió el legislador para describir el delito básico de solicitud de favores sexuales en el contexto de una relación laboral -que es la que aquí interesa- es muy semejante a la del art. 173.1, párrafo segundo, pues el acoso moral y el sexual en el trabajo tienen en común la afectación a la integridad moral de la víctima y el marco del delito, la relación laboral lato sensu. No obstante, el legislador, en lo que no puede interpretarse sino como relajación frente a las exigencias de la lex certa, recurre, sin justificación explicable, a una redacción distinta en cada uno de los preceptos: en el acoso sexual lo hostil o humillante -a lo que se añade lo intimidatorio- es el resultado; en el moral, estos adjetivos califican a los medios ("los actos"). En el acoso sexual, el marco es "cualquier relación laboral o funcionarial"; en el sexual "una relación laboral, docente o de prestación de servicios, continuada o habitual".

La medida de seguridad de libertad vigilada, introducida por la LO 5/2010, "resulta aplicable -y este es el núcleo de ruptura con el sistema anterior- no sólo cuando el pronóstico de peligrosidad del individuo se relaciona con estados patológicos que han determinado su inimputabilidad o 
semiinimputabilidad, sino también cuando la peligrosidad deriva del especifico pronóstico del sujeto imputable en relación con la naturaleza del hecho cometido, siempre y cuando el propio legislador así lo haya previsto de manera expresa" (EM. 4). Se impone a sujetos presuntamente peligrosos, pero cuya peligrosidad se vincula, al menos en la fase de imposición inicial, no a las características de la persona, sino a las del hecho cometido ${ }^{10}$. Es el caso de los delitos contra la libertad e indemnidad sexuales, y, entre ellos, del art. 184 (art. 192.1).

El fundamento legitimador de esta medida resulta más que débil, por asentarse en una peligrosidad presunta, iuris et de iure, -"se les impondrá..." es la fórmula taxativa del art. 192.1- carente de base empírica, y más aún cuando se proyecta sobre una gama tan heterogénea de delitos como los que integran el Título VIII. El automatismo queda, no obstante, mitigado cuando el delincuente primario es condenado por un único delito; en ese caso la imposición pasa a ser potestativa "en atención a la menor peligrosidad del autor" (art. 192.1). Por otra parte, en los delitos de acoso sexual laboral la pena de prisión es, junto a la de multa, una opción del juzgador, que siempre puede decidirse por esta, cerrando el paso a la aplicabilidad de la libertad vigilada.

En los casos en que una autoridad o funcionario "solicitare sexualmente" en los términos del art. 443 -modificado por LO 15/2003-, a quien tuviere, indirecta o mediatamente, "pretensiones pendientes de la resolución de aquel o acerca de las cuales deba evacuar informe o elevar consulta a su superior", se suscitan cuestiones concursales con el delito de acoso sexual no fáciles de resolver. En efecto, si concurriendo los elementos del art. 443, se provoca el resultado del 184 ("situación objetiva y gravemente intimidatoria, hostil o humillante”) parecería que este, cuando la relación autor-víctima

10 ACALE SÁNCHEZ, M., "Medidas de seguridad postpenitenciarias en el Código Penal Español: el movimiento de defensa social retro del siglo XXI”, en Revista de Derecho Penal, 2013 (20), p, 21, 
fuere también funcionarial, habría de ser, por especialidad o por consunción, ley preferente. Pero no puede aceptarse esta interpretación que llevaría a imponer la pena más leve del acoso sexual frente a la más grave de los abusos en la función pública. Lo que ha llevado al TS a otra propuesta: "ambos tipos contemplan una solicitud sexual no querida y consentida sino impuesta en base a razones o circunstancias especiales. Sin embargo, el artículo 443 añade como elemento nuevo, fundamento de la norma especial, la condición del sujeto activo que solo puede serlo un funcionario público" "11. Así, la apreciación del concurso normativo, permitiría aplicar el precepto con pena más grave, por ser ley especial. O, preferiblemente, por ser lex consumens.

\section{Sistema de seguridad social}

Los fraudes a la Seguridad Social (SS) despliegan una extraordinaria lesividad, que no se limita al menoscabo de las pretensiones recaudatorias del sistema. Afectan también a los derechos económicos de un colectivo de beneficiarios, actuales o potenciales, de las prestaciones previstas en el art. 42 del Texto Refundido de la Ley General de la Seguridad Social (LGSS). Y afectan, sobre todo, a derechos constitucionales no económicos de primer rango. En efecto, la $\mathrm{CE}$ ordena a los poderes públicos el mantenimiento de "un régimen público de SS para todos los ciudadanos que garantice la asistencia y prestaciones sociales suficientes ante situaciones de necesidad, especialmente en caso de desempleo" (art. 41).

La tipificación de los fraudes a la SS en el CP común responde a la tendencia imperante en el ordenamiento español de llevar las conductas delictivas a este, y no a leyes especiales $^{12}$. Pero la integración formal convive con discrepancias

11 Como propone la STS, $2^{\mathrm{a}}, 10.07 .2019$, Fundamentos de Derecho. Tercero (Ecli: ES:TS:2019:2349).

12 TERRADILlOS BASOCO, J.M., 2019, "Centralidad del CP común versus dispersión en leyes penales sectoriales", en MEDINA CUENCA, 
materiales. En efecto, los artículos 307 y 307 ter no se incorporaron al Código en el curso del debate parlamentario sistemático que dio lugar a la gran reforma penal introducida por la $L O 1 / 2015$, sino, antes, en los debates sobre la $L O 7 / 2012$, modificadora del CP "en materia de transparencia y lucha contra el fraude fiscal y en la SS". Se diría que el legislador -tal como hiciera también con la LO 6/1995 que modificó ciertos delitos contra la Hacienda Pública y la SS al margen de la discusión del CP de nueva planta de 1995- se obstina en dar a estos delitos una respuesta específica y autónoma, al margen de los principios y objetivos del conjunto del sistema: más en concreto, mientras el $\mathrm{CP}$ ha de responder, en términos generales, a una lógica preventiva, la configuración de los fraudes a la SS responde a la lógica recaudatoria propia de las leyes tributarias ${ }^{13}$.

En líneas generales, el perfil del defraudador a la SS responde en el $\mathrm{CP}$ a dos tipologías criminológicas distintas.

La primera está constituida por el trabajador que disfruta indebidamente una prestación. A tenor de la LGSS, art. 7, pueden ser titulares del derecho a prestaciones de modalidad contributiva los trabajadores por cuenta ajena o autónomos, los socios de cooperativas de trabajo asociado, los estudiantes y los funcionarios públicos, militares o civiles. Por su parte, el art. 38 describe el contenido de la acción protectora del sistema de la SS: desempleo, asistencia sanitaria, recuperación profesional, prestaciones económicas en situaciones de incapacidad temporal, maternidad, paternidad, invalidez, etc.

A., (coord.), Perspectiva multidimensional del conflicto penal: de la política criminal a la concreción normativa "la línea invisible". Libro Homenaje a la profesora Dra. María Acale Sánchez, Unijuris, La Habana, 2019, pp. 20-21.

13 DOLZ LAGO, M.J., "Los delitos contra la SS: entre la corrupción pública y la privada. Algunas claves frente al tsunami de la crisis económica y las quiebras del principio de igualdad", en Revista General de Derecho del Trabajo y de la SS, Madrid, 2014 (38), ap. II. http://www. iustel.com/v2/revistas/detalle_revista.asp?id $=12 \&$ numero $=38$ 
En definitiva, los titulares del derecho a prestaciones son, en términos prácticos, los trabajadores, y la forma más extendida de fraude a la SS, es la de percibir prestaciones por desempleo o jubilación sin reunir los requisitos o simultaneándolas con el trabajo irregular remunerado. Con anterioridad a la reforma de 2012, los tribunales venían aplicando el tipo de estafas, frecuentemente en concurso con falsedades, a quienes defraudaban al sistema de SS captando a trabajadores que no reunían condiciones para obtener la prestación por desempleo, a los que se proveía, mediante pago, de documentación falsa acreditativa de reunir los requisitos necesarios ${ }^{14}$.

La segunda tipología se identifica con un sujeto que, con capacidad de decisión en el ámbito empresarial ${ }^{15}$, responde a los perfiles del occupational crime y aporta a la estadística criminal la parte del león: la no afiliación por la patronal de sus trabajadores es la infracción más frecuente en la materia y multiplica por ocho el número de infracciones por disfrute indebido de prestaciones ${ }^{16}$.

Ambos perfiles encuentran ubicación diferenciada en el CP: el art. 307 ter castiga al primero, normalmente el trabajador; el art. 307, por su parte, castiga a quien defrauda por impago de cuotas o percepción de deducciones o devoluciones indebidas: normalmente, el empresario.

El legislador de 1912 ha diseñado, frente a esta criminalidad de perfiles criminológicos tan distintos, una respuesta penal diferenciada, en la que conviven la tolerancia cómplice para con ciertos delincuentes -hasta el punto de que esta parcela de nuestro ordenamiento punitivo ha sido

14 https://www.lasprovincias.es/sucesos/anos-carcel-abogado20200210134517-nt.html

15 MARTÍNEZ-BUJÁN PÉREZ, C., Derecho penal económico y de la Empresa, 5 ${ }^{\text {a }}$ ed., Tirant lo Blanch, Valencia, 2015, p. 670.

16 TERRADILlOS BASOCO, J.M., y BOZA MARTÍNEZ, D., El Derecho penal aplicable a las relaciones laborales. Lecciones, cit., pp. $163-$ 164. 
calificada, con razón, como "Derecho Penal del amigo"17, y el rigor exacerbado frente a otros. En efecto, aunque los artículos 307 y 307 ter comparten técnicas de inhibición punitiva - causas de atipicidad a posteriori (!), atenuaciones específicas con alcance excarcelatorio, etc.-, el primero añade otras exclusivas -condición objetiva de punibilidad ${ }^{18}$-, mientras que el 307 ter responde a patrones de acentuado punitivismo -criminalización de la bagatela, ausencia de condiciones objetivas de punibilidad, causas de atipicidad con condiciones más exigentes, ampliación de supuestos de autoría, etc.

\section{IV.1. Elusión del pago de cuotas y obtención indebida de beneficios económicos}

El tipo básico del art. 307.1. castigaba, en su versión inicial de 1995, al que "por acción u omisión, defraude a la SS para eludir el pago de las cuota... ... obtener indebidamente devoluciones de las mismas o disfrutar de deducciones... ... siempre que la cuantía de las cuotas defraudadas o de las devoluciones o deducciones indebidas exceda de quince millones de pesetas". La pena prevista era la de prisión de uno a cuatro años y multa del tanto al séxtuplo de lo defraudado.

La LO 5/2010 procedió, en clave punitivista, a una importante reforma, y no solo en materia de penas (ver infra, IV.2). También se modificó al alza, contradiciendo el fundamento de elevación de la pena, la cuantía de la condición objetiva de punibilidad: pasó de quince millones de pesetas a ciento veinte mil euros, equivalentes a veinte millones de pesetas.

La redacción actual procede de la $L O$ 7/2012, que redujo la cuantía de la condición objetiva de punibilidad a

17 VIDALES RODRÍGUEZ, C., "Derecho penal del amigo. Reflexiones críticas acerca de la reciente modificación de los delitos contra la Hacienda Pública y la SS)", en Revista de derecho y proceso penal, 2013 (32), p. 269.

18 Aunque el TS prefiera, en ocasiones, considerarlas "requisitos de procedibilidad": STS, 2a , 12.11.2019, Fundamentos de Derecho. Cuarto (Ecli: ES:TS:2019:3683). 
cincuenta mil euros, entendiendo que ese límite resultaba "conforme a criterios económicos, políticos y sociales... que ponen de relieve... la necesidad de actuar, con mayor contundencia, frente a las conductas presuntamente delictivas y tramas organizadas que ponen en peligro la sostenibilidad financiera del Sistema de la SS. La reducción de la cuantía del tipo delictivo permite que sean objeto de punibilidad penal hechos que actualmente sólo son sancionables administrativamente y que son objeto de un contundente reproche social" (Preámbulo. IV).

La nueva cifra refleja, no obstante, una inicial incoherencia: mientras en los delitos tributarios -tipo básico- o en los de fraude de subvenciones el tope está en los ciento veinte mil euros, en el caso de fraudes a la SS, del art. 307, la cuantía se fija en cincuenta mil; si se trata de fraude de subvenciones a la UE, el límite mínimo son cuatro mil; y en el caso de disfrute indebido de prestaciones de la SS, del art. 307 ter.1, el límite mínimo desaparece ${ }^{19}$.

Y, aún más, se registra una incoherencia político-criminal mayor. Con anterioridad a la $L O$ 7/2012, el art. 307 establecía como límite mínimo de la defraudación delictiva -considerándolo la doctrina ya condición objetiva de punibilidad ya como resultado típico-, el de ciento veinte mil euros en un año. A partir de esa ley, la cuantía defraudada ha de ser la de cincuenta mil en cuatro años (art. 307.2). Lo que tiene un efecto aparentemente endurecedor puesto que podrá incurrir en delito quien defraudare, en cada uno de esos cuatro años, doce mil quinientos euros Pero tiene también un efecto despenalizador: quien defrauda anualmente ciento veinte mil o más durante cuatro años -lo que supone un fraude total de cuatrocientos ochenta euros o más-, responderá por un solo delito, aunque agravado (art. 307 bis 1.b), y no por cuatro,

19 DE LA MATA BARRANCO, N.J., "Delitos contra la Hacienda Pública y la SS", en DE LA MATA BARRANCO et alii, Derecho Penal Económico y de la Empresa, Dykinson, Madrid, 2018, p. 572. 
como ocurría antes. Lo que supone no una intensificación de la presión penal sino, al menos para los grandes defraudadores, un trato más favorable ${ }^{20}$.

En cualquier caso, la cantidad objeto de defraudación se fija atendiendo al total de las cuotas defraudadas en las diferentes unidades económicas (empresas) controladas por el defraudador en cada período a computar ${ }^{21}$.

El art. 307 bis, introducido en la reforma de 2012, recoge circunstancias específicas de agravación, que amplían el catálogo de las incorporadas al texto de 1995 por la $L O$ 15/2003; aunque más nominal que realmente, puesto que pueden ser eludidas mediante la regularización o la atenuación por colaboración (ver infra IV.3.2 y 3.3).

\section{IV.2. Obtención indebida de prestaciones}

El art. 307 ter castiga a quien defraudare a la SS por disfrute indebido de prestaciones.

El Preámbulo. $I$ y $I V$, de la $L O 7 / 2012$, que introdujo ex novo el precepto, justificaba la criminalización por la necesidad de hacer frente a los comportamientos defraudatorios mediante la obtención indebida de subvenciones, antes subsumibles en el art. 308, pero solo cuando superaban la cuantía de ciento veinte mil euros. En realidad, también se pretendía superar una cuestión previa, la de decidir sobre la aplicabilidad del art. 248, apreciando estafa, o del 308, apreciando fraude de subvenciones.

La segunda cuestión requería clarificar el alcance del art. 308, limitado nominalmente al fraude de subvenciones "a las Administraciones Públicas", lo que suscitaba la duda jurisprudencial sobre la consideración como tal del siste-

20 STS, 2a , 05.10.2017, Fundamentos de Derecho. Tercero (Ecli: ES:TS:2017:3610)

21 STS, 2a , 12.11.2019, Fundamentos de Derecho. Cuarto (Ecli: ES:TS:2019:3683). 
ma de SS. La duda fue resuelta en sentido explícitamente afirmativo por el Acuerdo no Jurisdiccional de la Sala Segunda del TS de 15.02.2002 22 .

Aclarada la aplicabilidad, en principio, del art. 308, el TS pretendió resolver el aparente concurso de normas entre él y el art. 248, considerando inicialmente procedente apreciar una relación de especialidad, siendo lex specialis la que castiga la defraudación "especializada", y lex generalis, el tipo general de estafa ${ }^{23}$. Aunque otras resoluciones habían declarado preferente el art. 248 sobre el -subsidiario- 308, cuando los hechos enjuiciados reuniesen todos los elementos constitutivos de la estafa, por estar esta castigada, en el momento de los hechos, con pena mayor que el fraude de subvenciones $^{24}$. La reforma introducida por la $L O$ 7/2012, dejó definitivamente claro que la obtención fraudulenta de prestaciones de la SS debe ser subsumida en el art. 307 ter.

El nuevo 307 ter pudo, respetuoso con el principio de intervención mínima, haber confiado la defraudación de prestaciones en cuantía irrisoria al orden sancionador administrativo (LISOS, art. 26); máxime cuando, además, los supuestos que tipifica "cumplen todos los requisitos del delito de estafa, con lo que, en realidad, no se viene a cubrir laguna de punibilidad alguna"25. Pero prefirió adherirse a la tendencia punitivista inspiradora de toda la $L O 7 / 2012$, y elevó a la categoría de delito la defraudación de cualquier cantidad, incluso irrelevante, siempre que cause "un perjuicio a la

22 Acuerdos del Pleno no Jurisdiccional. Sala de lo Penal. Tribunal Supremo. Años 2000-2016. Actualización abril 2016, Gabinete Técnico. Sala de lo Penal, p. 33. http://www.poderjudicial.es/cgpj/es/Poder-Judicial/ Tribunal-SuprEMo/

23 Doctrina recogida en STS, $2^{\mathrm{a}}$, 23.01.2020, Fundamentos de Derecho. Séptimo (Ecli: ES:TS:2020:270).

24 STS, 2a , 28.11.2020, Fundamentos de Derecho. Noveno (Núm. Sentencia 1030/2013).

25 MARTÍNEZ-BUJÁN PÉREZ, C., Derecho penal económico y de la Empresa, cit., 692. 
Administración Pública" (art. 307 ter 1). En doctrina, se ha objetado que esta decisión legiferante "llama la atención"26.

Tal como se advirtió (supra, apartado IV), el sujeto activo será, de ordinario, el trabajador que disfruta una prestación normalmente de subsistencia. No se opone a ello la función que el legislador, en el Preámbulo. IV de la $L O$ 7/2012, asigna al art. 307 ter: "facilitar la persecución de las nuevas tramas organizadas de fraude contra la SS que, mediante la creación de empresas ficticias, tienen por único fin la obtención de prestaciones del sistema”. A pesar de la retórica declaración de intenciones, el propio legislador reconoce que el nuevo precepto "viene también" a facilitar ese objetivo, lo que significa que tiene otros: los fraudes de subvenciones no subsumibles, por su escasa cuantía, en el art. 308. Por otra parte, la equívoca asignación de objetivos no puede ocultar que las prestaciones indebidamente disfrutadas lo han de ser por parte de trabajadores, a los que normalmente será aplicable la atenuación del art. 307 ter 1, párrafo segundo, pero que constituirán el grueso de las "conductas fraudulentas" incriminadas ex novo. Para las grandes defraudaciones a la SS mediante la obtención indebida de subvenciones/prestaciones podría haber bastado, con algún ligero retoque, el vigente, entonces y ahora, art. 308.

Por razones de igualdad -esencial al paradigma del Estado constitucional- debería haberse incorporado al precepto, tal como ocurre en todos los delitos del Título XIV, una condición objetiva de punibilidad radicada en la cuantía de lo ilícitamente obtenido, superior, al menos, a los cincuenta mil euros, que es el límite en el art. 307.

La $L O$ 7/2012 prefirió criminalizar puras bagatelas, provocando, como "daño colateral", la confusión entre el orden sancionador penal y el administrativo, lo que no es de recibo en términos generales, y menos cuando, como es el caso,

26 DE LA MATA BARRANCO, N.J., "Delitos contra la Hacienda Pública y la SS", cit., p. 574. 
el ordenamiento laboral ya prevé el reintegro de lo ilegalmente percibido, la pérdida del derecho y sanciones pecuniarias.

No ayuda mucho a delimitar los ámbitos respectivos de lo penal y lo administrativo sancionador la doctrina jurisprudencial, que recuerda que el principio de intervención mínima vincula al legislador y no a los jueces. Lo que, siendo inobjetable, no solventa la cuestión de fondo, sino que se queda en sus aledaños. Para avanzar más, el TS, propone un criterio que apenas supera el umbral de lo tautológico: "la tipicidad, que es lo que permite cumplir con la exigencia del principio de intervención mínima. La tipicidad es el criterio que delimita la respuesta penal de forma que extramuros de ella quedan las restantes ilicitudes, cumpliéndose así el principio de intervención mínima"27.

La voluntad desmesuradamente represiva del nuevo delito se manifiesta no solo en las penas (ver infra, 4.3.1.), sino también en el elenco de sujetos criminalizados, ya que se castiga a quien "obtenga, para sí o para otro, el disfrute... ... o facilite a otros su obtención". Es decir, lo defraudatorio típico no se limita a la obtención de la prestación indebida; se extiende hasta incluir el facilitar a otro ese resultado. Con lo que se rompen los límites entre participación y autoría, y se eleva a la categoría de autor al responsable de comportamientos de cooperación que no deberían pasar de la mera complicidad ${ }^{28}$.

\section{IV.3. Sistema de sanciones}

\section{IV.3.1. Penas}

La defraudación en las formas básicas del art. 307.1, está castigada con penas de prisión, de uno a cinco años y multa del tanto al séxtuplo de la cantidad defraudada. La $L O$

27 STS, $2^{\mathrm{a}}$, 676/2019, de 23 de enero de 2020 (Ecli: ES:TS:2020:270), Fundamento de Derecho Quinto, con referencias a sentencias anteriores.

28 MARTÍNEZ-BUJÁN PÉREZ, C., Derecho penal económico y de la Empresa, cit., p. 693. 
10/1995 había fijado el máximo de duración de la prisión en cuatro años, pero elevó las penas la LO 5/2010 "al objeto de hacerlas más adecuadas y proporcionales a la gravedad de las conductas" (Preámbulo. XXIII).

La pena resulta moderada para alguna resolución judicial -aunque referida a un supuesto de defraudación de muy alta cuantía-, que se hace eco de la crítica doctrinal al tratamiento punitivo comparativamente privilegiado de estos fraudes: "Moderación punitiva ya en su conminación abstracta, que ha motivado que la doctrina describa la tarea del legislador en esta materia, como tolerancia cómplice para con ciertos delincuentes, e incluso la inserte en la categoría de "Derecho Penal del amigo". Especialmente cuando respecto a otras modalidades sancionadas en perjuicio de la SS, como el acceso a la prestación social de subsistencia, abundante en perfiles de personas de escasas o nulas rentas, deviene sancionada desde el primer euro" 29 .

La LO 7/2012, porque "se ha considerado procedente" (Preámbulo. IV) introdujo como principal innovación en materia sancionadora ${ }^{30}$ las penas accesorias de "pérdida de la posibilidad de obtener subvenciones o ayudas públicas y del derecho a gozar de los beneficios o incentivos fiscales o de la SS durante el período de tres a seis años" (art. 307.1). Su imposición es preceptiva y cumulativa tanto en el tipo básico como en el agravado, del art. 307 bis. Ante la parquedad de la motivación aportada por el legislador, hay que entender que la "procedencia" a que alude se asienta en la idoneidad preventiva de estas penas que frustran la posibilidad de

29 STS, 2a 12.11.2019, Fundamentos de Derecho. Cuarto (Ecli: ES:TS:2019:3683).

30 TERRADILlOS BASOCO, J.M., y BOZA MARTÍNEZ, D., "Fraude a la SS por elusión de pago de cuotas en la doctrina judicial. Sentencia 657/2017 del TS, Sala 2a de lo Penal, de 05.10.2017", en Revista de Derecho de la SS, 2018 (15), pp. 133-144. https://revista.laborum.es/index. php/revsegsoc/article/view/286 
enriquecimiento delictivo futuro por parte de un tipo criminológico de autor movido por el afán de lucro.

El art. 307 bis, incorporado al CP por la misma ley, amplió el abanico de circunstancias agravantes antes ubicadas en el art. 307: defraudación superior a ciento veinte euros, o cometida en el seno de una organización o grupo criminal, o utilizando técnicas que, como los paraísos fiscales o las sociedades pantalla, dificulte la identificación del sujeto responsable, de la cuantía defraudada o del patrimonio obligado frente a la SS. Además se intensificaron sus efectos agravatorios: la pena, que era la mitad superior de la correspondiente al tipo básico, pasó a ser prisión de dos a seis años y multa del doble al séxtuplo.

Esta agravación comporta, según observa el Preámbulo. IV, de la $L O 7 / 2012$, "la ampliación del periodo de prescripción del delito hasta los diez años, lo que resulta, fundamental en estos casos por su complejidad de difícil y tardía detección".

En el caso del art. 307 ter, la pena es de prisión, de seis meses a tres años. Pero, dado que la cuantía defraudada no tiene límite mínimo (salvo el de "causar un perjuicio" no cuantificado), la pena podrá ser, atendiendo al importe defraudado, a los medios empleados y a las circunstancias personales del autor, la de multa, del tanto al séxtuplo (art. 307 ter 1, párrafo segundo). La atenuación pone en evidencia la mala conciencia del legislador, pero no cambia la calificación jurídica de la conducta bagatelar como delito. Lo que, obsérvese, contradice la motivación esgrimida por el legislador en el Preámbulo.I de la $L O$ 7/2102, cuando arguye, para fundamentar la introducción del nuevo tipo, que "ofrece una respuesta eficaz frente a los supuestos de fraude con grave quebranto para el patrimonio de la SS".

Además, al igual que en el art. 307, y por las mismas razones, se impondrá al responsable "la pérdida de la posibilidad de obtener subvenciones y del derecho a gozar de los beneficios o incentivos fiscales o de la SS durante el periodo de tres a seis años". 
La pena del tipo básico resulta desproporcionadamente alta: comporta una pena carcelaria de facto, aplicable a conductas carentes de lesividad real y que, por su naturaleza, no trascienden el nivel de las infracciones administrativas. Y, aunque las infracciones más triviales pueden ser castigadas con multa, en caso de impago será sustituida por privación de libertad, en los términos del art. 53 CP.

Si el valor de las prestaciones obtenidas o disfrutadas excediera de cincuenta mil euros o hubieran concurrido las demás agravantes específicas del art. 307 bis.1, las penas serán: prisión de dos a seis años, multa del tanto al séxtuplo y la pérdida de posibilidad de obtener subvenciones, beneficios o incentivos, de cuatro a ocho años (art. 307 ter.2)

$\mathrm{Si}$ concurren los requisitos del art. 31 bis $\mathrm{CP}$, responderá la persona jurídica, con penas de multa que pueden ir del tanto al cuádruple de lo defraudado además de la pérdida de derechos a percibir ayudas o beneficios y, potestativamente, de la prohibición de contratar con las Administraciones Públicas, de disolución, suspensión de actividades, clausura de locales y establecimientos por un plazo, y prohibición de realizar en el futuro las actividades en cuyo ejercicio se hubiere cometido, favorecido o encubierto el delito e intervención judicial de la sociedad (art. 310 bis).

La ejecución de la pena de prisión eventualmente impuesta reviste, en estos delitos, ciertas peculiaridades. En efecto, el art. 308 bis.1, añadido también por la LO 1/2015, condiciona la suspensión de la ejecución de la prisión, además de a los requisitos generales del art. 80, a que "el penado haya abonado la deuda tributaria o con la SS, o que haya procedido al reintegro de las subvenciones o ayudas indebidamente recibidas o utilizadas", si bien esta exigencia se entenderá cumplida cuando el condenado facilite información suficiente sobre su patrimonio y asuma el compromiso de realizar los pagos o reintegros y las demás responsabilidades civiles en términos en los que "sea razonable esperar que el mismo será cumplido". 
Las "subvenciones o ayudas" que han de ser objeto de reintegro comprenden, sin merma del principio de legalidad, todas las deducciones, devoluciones y prestaciones de los artículos 307 y 307 ter. El alcance del art. 308 bis 1.1 ${ }^{\text {a }}$, que va referido a todos los delitos del Título, ha obliga al legislador a recurrir a la fórmula lingüística genérica, pero suficientemente descriptiva.

\section{IV.3.2. Regularización}

En la $L O$ 7/2012, la regularización (artículos 307.3 y 307 ter.3) antes entendida doctrinalmente como excusa absolutoria, pasa a ser una espuria causa de destipificación que "neutraliza completamente el desvalor de la conducta y el desvalor del resultado, de modo que hace desaparecer el carácter delictivo del inicial incumplimiento de la obligación con la SS" (Preámbulo. IV).

Una vez negada la tipicidad de la conducta (ipor un acto posterior!) queda negada la responsabilidad penal de los partícipes. Es más, los efectos destipificadores se extienden a las "irregularidades contables u otras falsedades instrumentales" previas y relacionadas teleológicamente con la defraudación. Aunque, en este caso, esos efectos se limitan a irregularidades y falsedades del defraudador ("que el mismo pudiera haber cometido") y no de sus partícipes.

Para lograr tan radicales efectos, la regularización exige, en el caso del art. 307.3. el "completo reconocimiento y pago de la deuda antes de que se le haya notificado la iniciación de actuaciones inspectoras dirigidas a la determinación de dichas deudas... o antes de que el Ministerio Fiscal o el Letrado de la SS interponga querella o denuncia"

La opción político-criminal seguida por el legislador responde, junto a la consabida complicidad con la delincuencia de cuello blanco, a consideraciones pragmáticas vinculadas a la lógica recaudatoria, ante la que ceden las finalidades preventivas propias del sistema penal. Es más, la regularización 
puede tener en el CP efectos criminógenos, por cuanto su eficacia destipificadora se extiende a los defraudadores habituales o integrados en organizaciones criminales. En estos casos, en los que el delincuente ya tiene previsto, dentro de su estrategia operativa, proceder a la regularización, la exención de responsabilidad le incentiva, pues sabe que, si el delito se descubriera, tiene siempre abierta la puerta para eludir la condena.

En coherencia con la opción tipificadora, que distingue dos delitos distintos definidos en los artículos 307 y 307 ter del CP, la regularización tiene en este características distintas a las de aquel.

En el 307 quedará exento de responsabilidad criminal, quien reconozca y pague la deuda; en el 307 ter quien "reintegre una cantidad equivalente al valor de la prestación recibida incrementada en un interés anual equivalente al interés legal del dinero aumentado en dos puntos porcentuales, desde el momento en que las percibió".

Ciertamente, la respuesta penal diferenciada no puede tener, en la ley, otra explicación que un presupuesto también diferente. Y ya se ha analizado que la única diferencia entre los artículos 307 y 307 ter es la atinente al sujeto activo: empresario en un caso, trabajador en el otro. Así, no solo han sido sacrificados los principios de ultima ratio y de lesividad: es aún más flagrante la violación del principio de igualdad, constituyendo a la norma penal no en medio de tutela de bienes jurídicos, sino en instrumento de discriminación punitiva asentada en razones de clase.

\section{IV.3.3. Atenuación por colaboración}

Una de las manifestaciones más clamorosas de sustitución de la función preventiva de la norma penal por la función recaudatoria lo constituye la atenuación por colaboración, introducida, también, por la LO 7/2012.

En efecto, la pena podrá ser reducida en uno o dos grados si el condenado, antes del transcurso de dos meses 
desde que fuera citado como imputado, hubiera reconocido judicialmente los hechos y satisfecho su deuda con la SS (artículos 307.5 y 307 ter.6) La reducción de pena significa, de hecho, que no se impondrán penas de prisión o que no serán ejecutadas con privación material de libertad.

Esta atenuante específica post-delictiva-que funciona como instrumento de negociación solo al alcance de delincuentes económicamente solventes ${ }^{31}$ - carece de justificación, pues beneficia a defraudadores que ya tuvieron a su alcance la posibilidad de quedar exentos de responsabilidad criminal regularizando previamente su situación, y, sin embargo, no lo hicieron. Item más: se trata de defraudadores que pueden haber incurrido en las agravantes específicas del art. 307 bis 1, y no parece razonable poner la elusión de la privación efectiva de libertad al alcance de quienes delinquieron implementando sofisticadas operaciones de ingeniería financiero-tributaria tan graves como la utilización de sociedades pantalla, de testaferros, de paraísos fiscales, o de todo ello. Es más, lo razonable es esperar de estas medidas tóxicas consecuencias criminógenas, pues garantizan al delincuente que, en el peor de los casos - descubrimiento del delito no prescrito-, no se hará efectivo el ingreso en prisión ${ }^{32}$.

La atenuación es aplicable a los partícipes en el delito que "colaboren activamente para la obtención de pruebas decisivas para la identificación o captura de otros responsables, para el completo esclarecimiento de los hechos delictivos o para la averiguación del patrimonio del obligado frente a la SS o de otros responsables del delito" (art. 307.5). La ampliación

31 IGLESIAS RÍO, Miguel Á., "Delitos contra la Hacienda Pública y la SS”, en ÁLVAREZ GARCÍA, Francisco Javier (dir.), Estudio crítico sobre el Anteproyecto de Reforma Penal de 2012, Tirant lo Blanch, Valencia, 2013, p. 825.

32 TERRADILlOS BASOCO, J. M., "Protección de los derechos económicos, sociales y culturales. Consideraciones político-criminales", en DEMETRIO CRESPO, E., (dir.), Derecho penal económico y teoría del delito, Tirant lo Blanch, Valencia, 2020, p. 77. 
de la atenuante resulta igualmente discutible. Sobre todo en su modalidad de "premio a la delación": rompe con los principios del sistema penal y refleja las limitaciones de una Administración que, impotente ante la opacidad empresarial fuerza los mecanismos penales, hasta hacerlos irreconocibles, para asegurarse migajas recaudatorias. Por ejemplo, dando menos importancia al delito que a la conducta posterior, que puede ser meramente reparadora o delatora.

\section{IV.3.4. Cuestiones concursales}

$\mathrm{El}$ art. $438 \mathrm{CP}$, cuya redacción procede de la $L O$ $1 / 2015$, viene a reforzar, aunque sin motivación cognoscible en su Preámbulo, la discriminación impuesta por los artículos 307 y 307 ter.

En la redacción anterior, el art. 438 castigaba a la autoridad o funcionario que, con abuso de su cargo, cometiere una estafa o apropiación indebida, con la pena señalada a estas en su mitad superior, e inhabilitación especial de dos a seis años. La reforma alteró el ámbito de tipicidad, suprimiendo la referencia a la apropiación indebida, pero añadiendo el fraude de prestaciones a la SS del art. 307 ter. E incrementó la pena: la señalada a esos delitos en su mitad superior "pudiéndose llegar hasta la superior en grado, e inhabilitación especial para empleo o cargo público y para el ejercicio del derecho de sufragio pasivo por tiempo de tres a nueve años, salvo que los hechos estén castigados con una pena más grave en algún otro precepto de este Código".

Se castiga, pues, al funcionario público que facilita a un trabajador el disfrute fraudulento de prestaciones del art. 307 ter. Las penas pueden llegar a nueve años de prisión, en caso de defraudación agravada. Ahora bien, esta específica cláusula agravatoria no es aplicable si el mismo funcionario colabora en la defraudación del empresario deudor de cuotas.

La concurrencia de defraudación y falsedades requiere la misma respuesta que antes de la reforma de 2010: los 
artículos 307 y 307 ter, en su actual redacción, al igual que el 248 y 308, integran una estrategia falsaria no siempre calificable como delito de falsedad. "En tales casos, el desvalor de la conducta sería abarcado en su integridad por el art. 307 ter operando la regla de absorción prevista en el art. $8.3 \mathrm{del} \mathrm{CP.} \mathrm{En}$ cambio, cuando "la simulación o tergiversación de hechos se ejecuta mediante la afectación del bien jurídico protegido por el delito de falsedad", procede apreciar un concurso medial ${ }^{33}$.

\section{IV.3.5. Cuestiones procesales}

Una vez iniciado el procedimiento penal, la regla general es la de archivo del expediente administrativo hasta tanto concluya $-\mathrm{y}$ a sus resultas - el proceso penal. Sin embargo, tal como dispone el art. 307.4 -y en términos muy semejantes, el 307 ter.4-, la existencia de un procedimiento penal no paralizará el expediente administrativo de liquidación y cobro de la deuda contraída con la SS, salvo que el Juez lo acuerde así previa prestación de garantía o, si no pudiere prestarse, salvo que acordare la suspensión con dispensa de garantía, en el caso de que apreciara que la ejecución pudiera ocasionar daños irreparables o de muy difícil reparación. A pesar de la convivencia de esta doble vía, el art. 307.4, establece que la liquidación administrativa "se ajustará finalmente a lo que se decida en el proceso penal".

La derogación del régimen general de concurrencia de procedimiento sancionador administrativo y procedimiento jurisdiccional penal no presenta ninguna ventaja aparente, $y$ sí muchos inconvenientes, derivados de la posibilidad cierta de pronunciamientos inicialmente distintos en ambos planos. Por no hablar de las conocidas perversiones del proceso penal cuando previamente se ha sustanciado un expediente administrativo en el que el presunto infractor puede facilitar pruebas o reconocer hechos determinantes del sentido de la

33 STS, $2^{\text {a }}$, 954/2017, de 22 de marzo de 2018, Fundamento de Derecho 2.4 . 
decisión judicial final, a expensas de la presunción de inocencia y del derecho al debido proceso.

La "inexplicable lentitud con que se tramitan estos procedimientos" actúa como factor multiplicador de estas deficiencias $^{34}$.

\section{Condiciones legales mínimas de trabajo}

El art. 311, que venía tipificando el denominado "delito social", fue objeto de modificación por parte de la $L O$ $7 / 2012$, que adicionó un nuevo número, el $2^{\circ}$. Por lo demás, se mantiene el texto de 1995, con la excepción de la pena de prisión, que se incrementa. Aunque no se explican, con datos criminológicamente contrastados, las razones en cuya virtud pueden ser castigadas con prisión de hasta seis años conductas que, con anterioridad, solo ameritaban prisión de hasta tres años. El legislador no explica: ni siquiera lo intenta, por cuanto la justificación que esgrime va referida a la necesidad de castigar las conductas de contratación ilegal del art. $311.2^{\circ}$, y no las de otros números (Preámbulo. V).

La reforma no ha sido, sin embargo, aprovechada por el legislador para plantearse la conveniencia de suprimir la referencia al contrato individual como fuente de derechos cuya negación o restricción resulta típica. A pesar de que la doctrina ha insistido en que la inclusión del pacto individual entre esas fuentes puede crear puntos de fricción con los principios de legalidad, de igualdad y de intervención mínima $^{35}$. Y a pesar de que los tribunales apenas se han manifestado sobre conductas condenatorias por imposición ilegal de condiciones laborales por debajo de lo estipulado en un contrato individual.

34 STS, 2a , 12.11.2019, Fundamentos de Derecho. Cuarto (Ecli: ES:TS:2019:3683).

35 MARTÍNEZ-BUJÁN PÉREZ, C., Derecho penal económico y de la Empresa, cit., p. 800. 
Tampoco se ha aprovechado la ocasión para aportar criterios legales que ayuden al juzgador a decidir si concurre o no abuso de situación de necesidad. Lo que es de lamentar cuando en la doctrina ${ }^{36} \mathrm{y}$ en las sentencias penales se arrastra desde 1995 el debate sobre si un mercado laboral afincado en cifras millonarias de desempleados es marco determinante de situación de necesidad en el solicitante de trabajo, o si, además, es necesario que concurran elementos específicos que, en cada caso, permitan afirmar esa situación. Al respecto, el TS tiene declarado que "el término 'imposición' [supone] ... una situación en la que el trabajador no tiene libertad de optar porque cuando la alternativa es dejar de trabajar e irse al paro, es claro que eso no es fruto de una opción libre". Para, a renglón seguido, aclarar que "el abuso de estado de necesidad debe tener más consistencia que la derivada de la ínsita situación de desigualdad que existe en el mercado laboral entre empleadores y trabajadores, porque de no ser así, todo incumplimiento debería tener acceso a la respuesta penal, máxime teniendo en cuenta la crisis económica que ha golpeado con especial fuerza a la clase trabajadora". Pero, como tampoco parece de recibo exigir requisitos de precariedad extrema, inhabilitantes del precepto, se impone identificar los imprescindibles elementos determinantes de la necesidad en el caso concreto, entendiendo por abuso de necesidad "un plus diferente a la mera desigualdad intrínseca que existe en las relaciones laborales, pero sin llegar a una interpretación tan restrictiva que convirtiera este tipo penal en un delito de imposible acreditación y existencia" ${ }^{37}$.

Finalmente, parece haber pasado desapercibido al legislador que la elevación de la pena del tipo básico (art. $311.1^{\circ}$ ) comporta la del tipo agravado (art. $311.4^{\circ}$ ), que pasa a estar castigado con prisión de seis a nueve años.

36 MARTÍNEZ-BUJÁN PÉREZ, C., Derecho penal económico y de la Empresa, cit., p. 802.

37 STS, 2a , 05.04.2017, Fundamentos de Derecho. Tercero (Ecli: ES:TS:2017:1303) 
La alta gravedad de la pena quizá debiera haber llevado a plantearse la tipificación del delito de trabajos forzados o de sometimiento a condiciones de servidumbre o esclavitud. Se trata de una opción extendida en Derecho comparado, que permitiría reservar a estas conductas penas privativas de libertad de duración relevante, aligerando las del art. $311.1^{\circ}$, $2^{\mathrm{o}}$ y $4^{\mathrm{o}}$, que castigan conductas de gravedad muy inferior ${ }^{38}$.

\section{Contratación ilegal}

Los delitos de contratación ilegal en sentido estricto están hoy regulados, con cierta anarquía sistemática, en los artículos $311.2^{\circ}$ y 311 bis. Ninguno de ellos figuraba en la versión del CP de 1995: el primero fue introducido por la $L O$ 7/2012; el segundo, sin que el legislador haya explicado sus razones $^{39}$, por la $L O 1 / 2015$.

Ambos están integrados en la misma estrategia político-criminal: asegurar el fair play en la competencia empresarial, adulterada cuando uno de los jugadores se lucra de las ventajas que proporciona el servirse de trabajadores irregulares. Lo que, por pura coherencia, debería haber aconsejado ubicar estos preceptos al margen del Título $\mathrm{XV}^{40}$.

38 TERRADILLOS BASOCO, J.M., "Explotación laboral, trabajo forzoso, esclavitud. ¿Retos político-criminales para el siglo XXI?”, en DEMETRIO CASTRO, E., y NIETO MARTÍN, A. (dir.), Derecho penal Económico y Derechos Humanos, Tirant lo Blanch, Valencia, 2018, p.237.

39 NAVARRO CARDOSO, F., "El delito de contratación ilegal del art. 311 bis CP: un nuevo despropósito, y un viejo vicio, legislativo", en DE LA CUESTA AGUADO, P.M., et alii (coord.), Liber amicorum. Estudios jurídicos en Homenaje al Prof. Dr. Dr. H.c. Juan $\mathbf{M}^{\mathrm{a}}$ Terradillos Basoco, Tirant lo Blanch, Valencia, 2018, p. 1049.

40 BENÍTEZ ORTÚZAR, I.F., 2018, "A propósito de los nuevos artículos 311.2 CP y 311 bis CP ¿Delitos contra los derechos de los trabajadores?, en DE LA CUESTA AGUADO, P.M., et alii (coord.), Liber amicorum. Estudios jurídicos en Homenaje al Prof. Dr. Dr. H.c. Juan Ma Terradillos Basoco, Tirant lo Blanch, Valencia, 2018, p. 1043. 
Por otra parte, ambos preceptos tienen la misma estructura: elevan al plano penal conductas de contratación ilegal, ya sancionadas en el ámbito administrativo. De ahí que la reforma, en este punto, apenas si trasciende el nivel de lo simbólico, puesto que las conductas convertidas en delito encontraban con anterioridad castigo relevante en aplicación de la LISOS. Es más, en algunos supuestos de contratación de extranjeros en situación irregular, la pena correspondiente al delito puede ser inferior a la sanción que le correspondería de haberse considerado la conducta infracción administrativa.

La protección penal se extiende a los trabajadores de facto, a pesar de que sus contratos puedan ser nulos para el Derecho laboral ${ }^{41}$, porque tal tacha no comporta mengua de derechos: "Considerar solo sujeto pasivo de este derecho al trabajador legal... llevaría a una concepción que crearía unas situaciones inaceptables de desigualdad social, porque el empleador podría imponer a los trabajadores ilegales las condiciones laborales más discriminatorias sin riesgo alguno de infracción legal...". En consecuencia, se considera relación laboral a toda "prestación de servicios por cuenta ajena, habitualidad en los mismos, dependencia, retribución y jornada... que tendría cabida [una vez regularizada] en el art. $1.1^{\circ}$ del Estatuto de los Trabajadores"'42.

\section{VI.1. Contratación simultánea de una pluralidad de trabajadores}

Con el nuevo $\mathrm{n}^{\circ} 2$ del art. 311 el legislador pretendía garantizar el "correspondiente reproche penal" a la utilización de mano de obra sin formalizar su situación ante la SS o sin la correspondiente autorización para trabajar. Se trata de comportamientos de lesividad evidente: niegan derechos que,

41 LASCURAíN SÁNCHEZ, J.A., "Delitos contra los derechos de los trabajadores", en DE LA MATA BARRANCO, N., et alii, Derecho Penal Económico y de la Empresa, Dykinson, Madrid, 2018, p. 603.

42 STS, 2a 17.05.2017, Fundamentos de Derecho. Tercero (Ecli: ES:TS:2017:1908) 
en materia de SS, corresponden a los trabajadores, incluso si "irregulares", y distorsionan la competitividad empresarial, por cuanto el infractor puede ofertar bienes y servicios " $a$ unos costes laborales muy inferiores a los que han de soportar aquellos otros que lo hacen cumpliendo con sus obligaciones legales" (Preámbulo. V). Sin embargo, el legislador no explica las razones por las cuáles los comportamientos criminalizados no son subsumibles en el art. 307, como fraudes a la SS, o no son tratados, en su faceta de atentatorios a la libre competencia, entre los delitos que la impiden o condicionan.

En definitiva, el art. $311.2^{\circ}$, castiga a "Los que den ocupación simultáneamente a una pluralidad de trabajadores sin comunicar su alta en el régimen de la SS que corresponda o, en su caso, sin haber obtenido la correspondiente autorización de trabajo, siempre que el número de trabajadores afectados sea al menos de: a) el veinticinco por ciento, en las empresas o centros de trabajo que ocupen a más de cien trabajadores, b) el cincuenta por ciento, en las empresas o centros de trabajo que ocupen a más de diez trabajadores y no más de cien, o c) la totalidad de los mismos, en las empresas o centros de trabajo que ocupen a más de cinco y no más de diez trabajadores".

La contratación de un solo trabajador sin autorización de trabajo o sin formalizar su alta en el sistema de SS constituía uno de los ejemplos de aplicabilidad del viejo art. 311 , en su $\mathrm{n}^{\circ} 1^{\circ}$. Era una de las formas tradicionales de imposición ilegal -mediante engaño o abuso de situación de necesidad- de condiciones de trabajo. En el actual $n^{\circ} 2^{\circ}$, en cambio, no importan los medios teleológicamente dirigidos a imponer, sino el hecho de dar ocupación, con independencia de que concurra la voluntad -no viciada por el engaño ni condicionada por la necesidad-concorde del trabajador.

La artificiosa aritmética legal deja ayunas de protección penal áreas de ocupación laboral cuantitativamente muy importantes. Es, en efecto, atípica la contratación en períodos sucesivos como lo es la de trabajadores en número 
inferior al determinado por los porcentajes requeridos, por ejemplo, la contratación simultánea de doscientos cincuenta trabajadores por empresas cuya plantilla supere los mil, o la de la totalidad de la plantilla si el número de trabajadores no excede de diez.

\section{VI.2. Contratación de extranjeros o menores sin per- miso de trabajo}

El nuevo art. 311 bis responde al objetivo de "culminar la trasposición efectiva de la Directiva 2009/52/CE” (LO 1/2015, Preámbulo. $X X V)$. Al respecto, la Directiva se hace eco de la acreditada insuficiencia de las sanciones administrativas y, en consecuencia considera necesario "disuadir a determinados empleadores poco escrupulosos" mediante la aplicación de sanciones penales. (Considerando 21). Así, a tenor de su art. 10, los Estados miembros "tomarán las medidas necesarias para garantizar que las personas físicas que cometan el delito ....... sean objeto de sanciones penales efectivas, proporcionadas y disuasorias". Y, dado que "muchos empleadores son personas jurídicas", estas "deben poder ser consideradas responsables por los delitos contemplados en la presente Directiva" (Considerando 25), como reitera el art. 11.

De acuerdo con el primero de los imperativos comunitarios mencionados - pero no con el segundo-, el art. 311 bis castiga con prisión de tres a dieciocho meses o multa de doce a treinta meses a quien " a) de forma reiterada, emplee o dé ocupación a ciudadanos extranjeros que carezcan de permiso de trabajo, o b) emplee o dé ocupación a un menor de edad que carezca de permiso de trabajo".

En relación con los ciudadanos extranjeros, sorprende que el legislador haya introducido una nueva modificación en 2015 cuando aún no se habían manifestado los efectos prácticos de la reforma de 2012 materializada en el apartado $2^{\circ}$ del art. $311 \mathrm{CP}$ que, en cierta medida, comparte alguno de los supuestos punibles con la letra a) del 311 bis. Como 
sorprende, al menos como muestra de cierta desidia legiferante, utilizar el término "permiso" -en desuso a raíz de la Disposición Adicional Única de la LO 14/2003 que reformó la LO 4/2000, de 11 de enero, sobre derechos y libertades de los extranjeros en España y su integración social (LOEx)- para referirse a la autorización de trabajo exigida a los ciudadanos extranjeros.

La reforma tiene carácter fundamentalmente simbólico y efectos contradictorios, pues tanto la LISOS, en su art. 37, como la LOEx, en su art. 54.d), ya sancionan la contratación de trabajadores extranjeros sin haber obtenido con carácter previo la correspondiente autorización de residencia y trabajo. En el caso de la normativa de extranjería, se incurre en una infracción por cada uno de los trabajadores, siempre que el hecho no constituya delito. La aplicación del art. 311 bis CP puede, así, suponer un beneficio para el empleador, que pasaría de ser sancionado con una multa administrativa de entre 10.001 y $100.000 €$ por cada trabajador afectado, a una pena única, independientemente de los trabajadores afectados, que puede consistir en una multa de entre doce y treinta meses $^{43}$. Y, en la materia, sigue siendo una constante que los tribunales impongan las penas de multa tomando como cuota-base cuantías irrisorias ${ }^{44}$.

La superposición de lo penal y lo infraccional administrativo exige del aplicador de la norma recurrir a criterios

43 TERRADILlOS BASOCO, J.M., y BOZA MARTÍNEZ, D., El Derecho penal aplicable a las relaciones laborales. Lecciones, cit., p. 92.

44 STS, 2a , 05.11.2019 (Ecli: ES:TS:2019:3660): condena en instancia de intermediario/empresario agrícola, cuota de 8 euros/día; STS, $2^{\mathrm{a}}$, 28.09.2017 (Ecli: ES:TS:2017:3389): ganaderos, propietarios de rebaño de rebaño de 1600 ovejas y algo más de 100 cabras, cuota 10 euros/ día; STS, 2a , 05.04.2017 (Ecli: ES:TS:2017:1303): administrador, socio y propietario de sociedades mercantiles, entre ellas empresa Municipal de Aguas de Córdoba, cuota 25/euros día; STS, 2a, 20.02.2020 (Ecli: ES:TS:2020:595):empresarios titulares de varios "clubes de alterne", cuota 10 euros/día, etc. 
delimitadores no suministrados por el legislador. En concreto, la lesividad material -en el sentido de resultado de lesión o de peligro- para derechos de los trabajadores debe constituir el primero de esos criterios.

El delito de empleo de menores sin permiso de trabajo se conforma, al contrario de lo que ocurre con los ciudadanos extranjeros, con un solo acto de contratación sobre un solo menor ${ }^{45}$. Y en lo relativo al permiso de trabajo, conviene tener presente que el art. 6 ET prohíbe el trabajo de menores de 16 años, con la excepción de su participación en espectáculos públicos previa autorización de la autoridad laboral, y el de menores de entre 16 y 18 años no emancipados o que carecieren de previa autorización paterna. Los menores comprendidos en el art. 311 bis $\mathrm{CP}$ son, frente a lo mantenido por alguna opinión doctrinal ${ }^{46}$, todos, no solo los extranjeros, y así lo confirman tanto el CP como la Directiva 2009/52/CE, que cuando quieren referirse a la condición de extranjería, lo hacen explícitamente.

La pena es alternativa: prisión de 3 a 18 meses o multa de 12 a 30 meses, con máximos muy por debajo de los contemplados en el art. $311 \mathrm{CP}$. Además, el propio precepto establece su carácter subsidiario. A este respecto, debe considerarse que, en el ámbito de los trabajadores extranjeros, su contenido coincide, en gran parte de los casos, con el art. 312.2 que, de acuerdo a esta cláusula de subsidiariedad, tendrá aplicación preferente.

El apartado 2 in fine del art. 312 castiga, en términos que no han variado desde 1995, una conducta similar a la del 311 bis a), la de emplear a "súbditos extranjeros sin permiso de trabajo en condiciones que perjudiquen, supriman o restrinjan

45 MARTÍNEZ-BUJÁN PÉREZ, C., Derecho penal económico y de la Empresa, cit., p. 816.

46 AGUADO LÓPEZ, S., "Delitos contra los derechos de los trabajadores”, en BOIX REIG, J. (dir.), LLORIA GARCÍA, P. (coord.), Diccionario de Derecho Penal Económico, 2a ed., Iustel, Madrid, 2017, p. 399. 
los derechos que tuviesen reconocidos por disposiciones legales, convenios colectivos o contrato individual". En ambos casos la conducta consiste en emplear a extranjeros sin autorización, de forma reiterada en el art. 311, de forma que queden perjudicados o suprimidos sus derechos laborales en el 312.

El resultado lesivo explica la penalidad más intensa que cuando no concurre ${ }^{47}$. Por lo mismo, la contratación reiterada de extranjeros con perjuicio o supresión de sus derechos (312.2) entra en relación de consunción con la mera contratación irregular (311 bis a).

\section{Tráfico ilegal de mano de obra}

El art. 312.1 castiga con prisión de dos a cinco años y multa de seis a doce meses a quienes trafiquen de manera ilegal con mano de obra. La pena fue introducida por la LOEx 4/2000, sustituyendo a la originaria del CP de 1995: prisión de seis meses a tres años y multa de seis a doce meses.

Aunque la formulación típica no haya cambiado, sí lo ha hecho el contenido material del precepto. En efecto, el tráfico ilegal puede revestir dos formas -colocación de personas al margen de los mecanismos legales y cesión ilegal de mano de obra- y en las dos, el carácter legal o ilegal viene determinado por la normativa laboral, especialmente por el art. 16 de la LISOS, modificada por Ley 30/2015, y por el art. 43 del ET, Real Decreto Legislativo 2/2015.

En un ordenamiento penal presidido por el principio de lesividad, la irregularidad de la colocación o de la cesión no puede determinar, per se, la apreciación de delito: esta ha de quedar limitada a los casos en los que concurra lesión o puesta en peligro relevantes de los derechos de los trabajadores, por lo que resulta especialmente criticable que el legisla-

47 STS, 2a 17.05.2017, Fundamentos de Derecho. Tercero (Ecli: ES:TS:2017:1908). 
dor se haya abstenido de aportar la exigible certeza, y haya declinado la posibilidad de "incluir factores típicos de restricción... que denoten una aptitud lesiva para el bien jurídico"48.

El apartado 2 del art. 312, inciso primero, mantiene su redacción original.

\section{Favorecimiento de la emigración ilegal}

El art. 313, en cambio, ha sido objeto de importantes reformas.

Más allá de las determinadas por la LO 13/2007, que modificó también el art. 23.4 de la $L O$ del Poder Judicial, declarando competente a la jurisdicción española para conocer de los delitos de tráfico ilegal o inmigración clandestina de personas, trabajadoras o no, cometidos por españoles o extranjeros fuera del territorio nacional, el texto actual del art. 313, CP que castiga al que determinare o favoreciere la emigración de alguna persona a otro país, "simulando contrato o colocación, o usando de otro engaño semejante", se debe a la $L O 5 / 2010$, que además introdujo el art. 177 bis, para castigar la trata de seres humanos, como delito distinto al de favorecimiento de la inmigración ilegal, objeto del, también reformado, art. 318 bis.

La emigración ha sido un fenómeno tradicionalmente presente en España, y, en los últimos años, como consecuencia del enquistamiento estructural de un alto nivel de desempleo en la economía, sigue creciendo. Si en 2009 el número de españoles residentes en el extranjero era de 1.471.691, en enero de 2019 subió a 2.545.729. Por continentes, el 61,\% tenía fijada su residencia en América y el 35,4\% en Europa ${ }^{49}$.

48 MARTÍNEZ-BUJÁN PÉREZ, C., Derecho penal económico y de la Empresa, cit., p. 820.

49 https://www.ine.es/prensa/pere_2019.pdf 
Esta realidad ha provocado la proliferación de ofertas de empleo foráneo, cuya eficacia engañosa viene potenciada por las nuevas tecnologías de la información, ante las que el sistema penal no puede inhibirse, y a este objetivo respondió la $L O 5 / 2010$, que, sin embargo, dejó sin cerrar el flanco de la inmigración laboral, expulsada del anterior art. 313.1, y no incorporada, en contra de lo declarado, por el nuevo art. 318 bis (Preámbulo. XII), que castiga delitos contra los derechos de los ciudadanos extranjeros, pero no contempla los ataques a sus derechos específicos como trabajadores, cuya consideración expresa y alta valoración da sentido a todo el Título XV.

Este déficit podría haber sido cubierto si el legislador hubiera aceptado incluir entre las circunstancias agravantes del art. 318 bis 4, la condición de inmigrantes por razón de trabajo -"mano de obra", dice el art. 312.1- de las víctimas. Pero no lo hizo, y, así, la derogación del anterior 313.1 vino a reflejar una sensible inhibición en materia de protección penal de los derechos de los trabajadores extranjeros, como manifestación de una política criminal dirigida, según confiesa la $L O$ 5/2010 (Preámbulo. XII) no tanto a "la protección de la dignidad y la libertad de los sujetos pasivos que la sufren", que es el objetivo que "prevalece" en el art. 177 bis, sino a "la defensa de los intereses del Estado en el control de los flujos migratorios".

El delito de trata de seres humanos del art. 177 bis (ver infra, XII), también introducido por la LO 5/2010 castiga conductas que pueden presentar zonas comunes con las de favorecimiento de la emigración ilegal, cuando el medio para lograr el consentimiento de la víctima sobre el desplazamiento migratorio fuese el engaño. La diferencia radica en que la trata exige finalidad de posterior "imposición de trabajo o de servicios forzados, la esclavitud o prácticas similares a la esclavitud, a la servidumbre o a la mendicidad". Cuando el engaño consiste en la mera simulación de contrato de trabajo o de sus condiciones esenciales, pero no hasta el punto de que 
estas equivalgan a trabajos forzados o sean similares a las de la esclavitud o servidumbre, no es aplicable el art. 177 bis.

\section{Discriminación}

El art. 314 castiga, desde 1995, los delitos de discriminación laboral. La LO 1/2015 sustituyó, en el catálogo de motivos discriminatorios típicos, la "minusvalía" por la "discapacidad".

También la circunstancia agravante cuarta del art. 22 -"cometer el delito por motivos racistas, antisemitas u otra clase de discriminación...." ha podido tener incidencia frente a la discriminación laboral, y más cuando el art. 314 ha acreditado reiteradamente su poca aplicabilidad y nula eficiencia ${ }^{50}$. A falta de apreciación de concurrencia de los requisitos típicos del art. 314, puede entrar en juego la agravante genérica.

Lamentablemente, veinticinco años de práctica inaplicación no han sido razón suficiente para que el legislador revisara un precepto cuya formulación originaria "guarda, de modo premeditado, las claves que impiden su aplicación en la práctica" ${ }^{\text {1. }}$. En efecto, no solo la redacción endiablada cierra las posibilidades de aplicación judicial, tal como denunciara en 2014 la Fiscalía de Barcelona ${ }^{52}$; además, si se aplicare, poca eficacia preventiva podrá desplegar, dada la parvedad de la pena prevista, en muchos casos más liviana que la paralela sanción administrativa ${ }^{53}$.

50 TAPIA BALLESTEROS, P., La discriminación laboral. Análisis del artículo 314 del Código penal, Tirant lo Blanch, Valencia, 2012, p. 347.

51 POMARES CINTAS, E., El Derecho Penal ante la explotación laboral y otras formas de violencia en el trabajo, cit., 143.

52 https://www.fiscal.es/mEMorias/mEMoria2014/FISCALIA_SITE/recursos/fiscalias/superiores/cataluna.pdf

53 TERRADILLOS BASOCO, J.M., "Delitos contra los derechos de los trabajadores", en TERRADILLOS BASOCO, J.M., (coord.), Derecho Penal. Parte Especial (Derecho Penal Económico), $2^{\text {a }}$ ed., Iustel, Madrid, 2016, p. 286. 


\section{Libertad sindical y derecho de huelga}

La protección penal de la libertad sindical y del derecho de huelga está encomendada, principalmente, al art. 315, cuya redacción actual procede de la $L O$ 1/2015.

Este es su tenor: "1. Serán castigados con las penas de prisión de seis meses a dos años o multa de seis a doce meses los que, mediante engaño o abuso de situación de necesidad, impidieren o limitaren el ejercicio de la libertad sindical o el derecho de huelga. 2. Si las conductas reseñadas en el apartado anterior se llevaren a cabo con coacciones serán castigadas con la pena de prisión de un año y nueve meses hasta tres años o con la pena de multa de dieciocho meses a veinticuatro meses. 3. Quienes actuando en grupo o individualmente, pero de acuerdo con otros, coaccionen a otras personas a iniciar o continuar una huelga, serán castigados con la pena de prisión de un año y nueve meses hasta tres años o con la pena de multa de dieciocho meses a veinticuatro meses".

En la fórmula original, de 1995, la conducta del apartado 1 era idéntica, aunque la pena resultaba notoriamente más grave : "de prisión de seis meses a tres años y multa de seis a doce meses".

En el apartado 2, el comportamiento típico ha cambiado: el medio tasado actual -“coacciones"- era antes "fuer$z a$, violencia o intimidación". Y las penas, las superiores en grado a las del tipo básico antes de la $L O$ 1/2015, también han resultado reducidas.

El apartado 3 conserva, en cuanto a la conducta, la descripción inicial. Pero la pena es la misma del apartado 2, que, a su vez, es la misma que la establecida para las coacciones para impedir el ejercicio de un derecho fundamental: mitad superior de la pena del tipo básico de coacciones (art. 172.1, párrafo segundo). La pena anterior a la $L O ~ 1 / 2015$ era de prisión de tres a cuatro años y medio y multa, con la consecuencia de un rosario inacabado de actuaciones 
jurisdiccionales contra los piquetes de extensión de la huelga que han hecho tambalear, y así lo han denunciado organizaciones internacionales, el reconocimiento real del derecho de huelga en nuestro país.

Al reducir la pena, en su mínimo, a una multa, o al abrirse la posibilidad de que la pena de prisión sea susceptible de suspensión o de sustitución -lo que no ocurría con anterioridad-, el CP ha optado por una alternativa punitiva más compatible con la tutela de los derechos de los trabajadores en materia de libertad sindical y derecho de huelga, lo que ha provocado la valoración positiva de los sectores sindicales. Pero no puede olvidarse que, en sentido inverso, se ha relajado significativamente la presión penal frente a las conductas negadoras de esos derechos y libertades, castigadas en los dos primeros apartados del art. $315 \mathrm{CP}^{54}$.

En conjunto, en el plano sancionador, la reforma redujo notoriamente las penas, que pasan a ser alternativas -prisión o multa- en todos los casos. En el plano tipificador, se equipara la libertad positiva y negativa de huelga en los apartados 1 y 2 pero no en el 3 , que castiga una conducta coactiva específica contra el derecho a no participar en una huelga, y no contra el derecho de huelga, lo que encaja mal en un modelo constitucional en el que este, como derecho subjetivo público de la máxima jerarquía, debe prevalecer, en caso de conflicto, sobre aquel, que, en definitiva, no es sino una libertad o facultad genérica de menor consideración. Lo que lleva de la mano a entender que violaría el orden de valores constitucional una tutela penal del bien jurídico de inferior rango más enérgica que la que brindada al derecho fundamental de huelga ${ }^{55}$.

54 MARTÍNEZ-BUJÁN PÉREZ, C., Derecho penal económico y de la Empresa, cit., p. 855.

55 MARTÍNEZ-BUJÁN PÉREZ, C., Derecho penal económico y de la Empresa, cit., p. 858. 
La coacción, que hoy constituye el medio típico en el delito del art. 315.2, constituye también el modus operandi delictivo de los piquetes de extensión de la huelga -"actuando en grupo o individualmente, pero de acuerdo con otros"- del apartado 3.

El concepto de coacción hay que buscarlo en el art. 172 , objeto de varias reformas, la última por $L O 1 / 2015$, y en su interpretación por la doctrina jurisprudencial.

El art. 172 obliga, con carácter general, a tener en cuenta la gravedad de la coacción y los medios empleados. Lo que debe ser interpretado en su contexto: el marco de la huelga es un espacio de confrontación, en el que el ejercicio colectivo de un derecho por parte de una pluralidad de trabajadores se contrapone frontalmente al derecho a no hacerlo por parte de otros. En ese espacio de tensión entre derechos, uno de los cuales solo se puede ejercer válidamente de forma colectiva y, por tanto, tendencialmente expansiva, la determinación de qué comportamientos de defensa y difusión de la huelga adquieren el nivel de -penalmente-coactivos requiere acudir a estándares y criterios interpretativos más estrictos que los que se aplican en ámbitos no conflictivos. Así, conductas de coactividad menor, que, en abstracto, pudieran dar lugar a la aplicación del art. $172 \mathrm{CP}$, deben estimarse atípicas en relación con el $315.3 \mathrm{CP}$.

La coacción a otro, por parte de quien actúa solo, para iniciar o continuar una huelga no es subsumible en el art. 315.3, y debe ser examinada, como delito de coacciones, a la luz del art. 172 CP. Y, tratándose de un delito contra la libertad individual, la concurrencia de varios sujetos pasivos determina concurso de delitos. En cambio, en el art. 315.3, la expresión "a otras personas" lleva a apreciar un único delito cuando los coaccionados sean varios, en la línea de los derechos contra los trabajadores.

$\mathrm{Y}$ este es uno de los elementos esenciales a tener en cuenta, de lege ferenda, al valorar el art. 315.3, cuya derogación 
ha sido reivindicada con insistencia tanto en foros doctrinales $^{56}$ como políticos $^{57}$. Pues, de salir adelante las pretensiones derogatorias, el precepto que pasará a castigar las coacciones del piquete, el art. 172.1, párrafo segundo, tendrá un campo de aplicación más amplio que el del 315.3 -que exige actuación conjunta o concorde y dolo específico- y puede llevar a una penalidad superior en el caso, que será regla general, de pluralidad de coaccionados ${ }^{58}$.

La alternativa -en contra de las propuestas doctrinales, sindicales y políticas absolutamente mayoritarias ${ }^{59}-$ no es, pues, una derogación de consecuencias negativas para el derecho de huelga; pero tampoco el mantenimiento de un statu quo que ha convivido con la utilización espuria del art. 315.3 .

La formulación de alternativas requiere, recuperar el objetivo político-criminal esgrimido para avalar el nacimiento del art. 315.3: protección penal del derecho de huelga. Requiere también analizar, para evitarlas, las perversiones aplicativas que han convertido un medio legal de tutela de un derecho en instrumento de su negación ${ }^{60}$. Y requiere, finalmente,

56 MARTÍNEZ-BUJÁN PÉREZ, C., Derecho penal económico y de la Empresa, cit., p. 535.

57 DE VICENTE MARTÍNEZ, R., “¡Se acabaron las mayorías parlamentarias! Una crónica política hacia la criminalización del ejercicio del derecho de huelga", en DE LA CUESTA AGUADO, P.M., et alii (coord.), Liber amicorum. Estudios jurídicos en Homenaje al Prof. Dr. Dr. H.c. Juan $\mathrm{M}^{\mathrm{a}}$ Terradillos Basoco, Tirant lo Blanch, Valencia, 2018, pp. 10711074.

58 TERRADILLOS BASOCO, J.M., "De la huelga como derecho al piquete como delito: a propósito de la sentencia sobre el caso 'los 8 de Airbus", en Revista de Derecho Social, 2016 (73), p. 233.

59 DE VICENTE MARTÍNEZ, R., “¡Se acabaron las mayorías parlamentarias! Una crónica política hacia la criminalización del ejercicio del derecho de huelga", cit., pp. 1075-1081.

60 BAYLOS GRAU, A., y TERRADILlOS BASOCO, J.M., 2007, "Sobre el artículo 315 del Código Penal". http://baylos.blogspot.com. es/2007/04/sobre-el-articulo-3153-del-codigo-penal.html. 
adecuar la penalidad, atenuándola en consideración a los factores concurrentes en el caso: el trabajador no huelguista, siempre apoyado por las estrategias patronales y por la intervención policial, minimiza la presión de la huelga obrera y favorece a la contraparte; la norma penal debe reservarse para responder a coacciones que superen sustancialmente las manifestaciones coactivas propias de la tensión inherente a la huelga ${ }^{61}$; el huelguista, con su actuación coactiva, $y$, por ende, delictiva, está defendiendo un derecho fundamental a costa de sus propios intereses, por ejemplo, pérdida de salario, con los consiguientes posibles efectos atenuatorios de la responsabilidad penal ${ }^{62}$; la previsión de penas carcelarias, que dan lugar a la prisión provisional, supone añadir a la conminación de pena la amenaza cierta del despido, lo que supone que la ley penal actúa no en favor de la expansión de un derecho fundamental, como debe hacer según doctrina constitucional penal consolidada ${ }^{63}$, sino, en sentido contrario, en favor de su recorte ${ }^{64}$. Todas estas razones aconsejan el mantenimiento del precepto incriminador, pero con una rebaja sustancial de la pena, que no debería en ningún caso ser privativa de libertad. La pena carcelaria debería reservarse, sin mengua de eficacia preventiva, para las coacciones que excedieran el nivel propio de la actuación coactiva del piquete de extensión de la huelga ${ }^{65}$.

61 DOLZ LAGO, M.J., "Crisis económica y criminalización de los piquetes de huelga: claves para juristas", en La Ley, 23.10.2014, p. 7. http://www.upfiscales.com/wp-content/uploads/2014/10/Dolz-Crisisecono $\% \mathrm{C} 3 \% \mathrm{ACmica}-\mathrm{y}$-criminalizacio $\% \mathrm{C} 3 \% \mathrm{ACn}$-de-los-piquetes-dehuelga-Diario-La-Ley-23_10_2014-1.pdf

62 DOLZ LAGO, M.J., "Crisis económica y criminalización de los piquetes de huelga: claves para juristas", cit., p. 8.

63 Sentencia del Tribunal Constitucional 254/1988, de 21 de diciembre, Fundamento Jurídico 3.

64 LASCURAíN SÁNCHEZ, J.A., "Delitos contra los derechos de los trabajadores", cit., p. 621.

65 TERRADILLOS BASOCO, J.M.,'De la huelga como derecho al piquete como delito: a propósito de la sentencia sobre el caso 'los 8 de Airbus", cit., p. 238. 


\section{Vida y la salud de los trabajadores}

El CP de 1995 incorporó, como una de sus novedades más relevantes, los delitos de peligro contra la vida y la salud de los trabajadores de los artículos 316 y 317 , cuya redacción original no ha sido objeto de reformas. Pero sí lo ha sido la gradación de la imprudencia, que da contenido tanto al art. 317 como a los artículos 142 y 152 , modificados a su vez por las Leyes Orgánicas $1 / 2015$ y 2/2019, incriminadores de la causación imprudente de muerte o lesiones, que habían venido constituyendo la respuesta tradicional a la siniestralidad laboral.

Aunque se han dictado sentencias condenatorias por delitos de peligro dolosos, con dolo eventual ${ }^{66}$, contra la vida y salud de los trabajadores, la regla general es el castigo por comportamientos imprudentes por aplicación del art. 317, que exige que la imprudencia sea grave. La leve quedó destipificada por la reforma operada por $L O 1 / 2015$. Y la menos grave -que no se corresponde con la despenalizada imprudencia leve, sino que incluye también supuestos antes integrados en la grave ${ }^{67}$ - debe ser llevada, cuando causante de resultado lesivo, a los artículos 142 o 152 . Lo que conduce a una deducción obvia: el ámbito de aplicación del art. 317 -y también del 142.1 y 152.1 - ha quedado reducido, en la medida en que han quedado reducidos los supuestos de imprudencia grave.

Esta relajación en la protección penal de la vida y salud de los trabajadores contrasta con lo exigido por los datos de la siniestralidad. En 2019 murieron, como consecuencia

66 MÉNDEZ RODRÍGUEZ, C., "La técnica de tipificación y su relación con la aplicación de los delitos", en DE LA CUESTA AGUADO, P.M., et alii (coord.), Liber amicorum. Estudios jurídicos en Homenaje al Prof. Dr. Dr. H.c. Juan $\mathrm{M}^{\mathrm{a}}$ Terradillos Basoco, Tirant lo Blanch, Valencia, 2018, p. 1103.

67 SAP Madrid, sec. $7^{\mathrm{a}}, 21.09 .2016$, Fundamentos de Derecho. Tercero (Ecli:ES:APM:2016:9758). 
de accidentes laborales, 695 trabajadores, 147 de ellos en la construcción. El repunte de las cifras sobre las de años anteriores puede deberse a un incremento de la actividad económica, y así razonan quienes entienden equivocadamente que los accidentes laborales son un penoso peaje a pagar, como daño colateral inevitable, al desarrollo ${ }^{68}$. Pero la falacia se desvanece cuando se observa que, en los años del boom de la construcción, entre 2000 y 2005, la cifra se redujo. La causa del actual remonte solo puede deberse, señalan todas las fuentes, a la precariedad en la contratación y a la consiguiente vulnerabilidad del trabajador, impotente para reivindicar, ni personal ni asociativamente, el cumplimiento de la normativa de prevención ${ }^{69}$.

\section{Trata de seres humanos}

El Preámbulo. XII, de la LO 5/2010 justifica, con cierta parquedad argumental, la introducción en el CP de un nuevo Título -el VII bis-denominado "De la trata de seres humanos", por la necesidad de separar la trata de la inmigración clandestina, objeto hasta entonces de un "tratamiento penal unificado", que daba lugar a "constantes conflictos interpretativos" e ignoraba compromisos internacionales asumidos por España, especialmente el Protocolo de Palermo. Un nuevo compromiso, la Directiva 2011/36/UE, y la resiliente necesidad de diferenciación nítida de los mencionados delitos -que, según se reconoce, no había logrado el texto de 2010 fueron las razones determinantes de la reforma introducida por la LO 1/2015 (Preámbulo. I).

68 SÁEZ VALCÁRCEL, R., "Morir en el trabajo. Política criminal frente a los accidentes laborales", en SÁEZ VALCÁRCEL, R., (coord.), Siniestralidad laboral y Derecho penal, Consejo General del Poder Judicial, Madrid, 2006, pp. 47-48.

69 https://www.eldiario.es/economia/Atencion-muriendo-obreros_0_995651165.html 
El apartado 1 del nuevo art. 177 bis, define el comportamiento del tipo básico de trata de seres humanos en términos que luego ampliaría la $L O 1 / 2015$, sentando las bases para la diferenciación definitiva entra trata e inmigración clandestina, y añade a esa función sistemática otra políticocriminalmente más relevante: "tipifica un delito en el que prevalece la protección de la dignidad y la libertad de los sujetos pasivos que la sufren" (Preámbulo. XXV).

En efecto, el nuevo delito atenta gravemente a la dignidad de la víctima, considerándola instrumento más que persona. Y atenta también a su libertad, en cuanto instancias ajenas deciden qué hacer con ella. En consecuencia, constituye un delito autónomo e independiente, desde el punto de vista normativo, de los delitos de explotación posteriores, a los que sirve instrumentalmente.

En coherencia con la naturaleza personalísima de los bienes jurídicos afectados, se debe apreciar tantos delitos como víctimas, en concurso real, tal como estableció el Acuerdo del TS de 31.05.2016 ${ }^{70}$.

La definición internacional de trata de seres humanos integra tres elementos: la conducta típica de índole traslativa, los medios comisivos para obtener el control de la víctima y la finalidad de explotación ulterior ${ }^{71}$. La primera de las modalidades de explotación es "a) La imposición de trabajo o de servicios forzados, la esclavitud o prácticas similares a la esclavitud, a la servidumbre o a la mendicidad".

A partir de la proclamación del derecho a trabajar como "el derecho de toda persona a tener la oportunidad de ganarse la vida mediante un trabajo libremente escogido o aceptado" (Pacto Internacional de Derechos Económicos, Sociales y

70 Cfr. STS, 2a, 20.02.2020, Fundamentos de Derecho. Decimocuarto (Ecli: ES:TS:2020:595).

71 TERRADILLOS BASOCO, J.M., y BOZA MARTÍNEZ, D., El Derecho penal aplicable a las relaciones laborales. Lecciones, cit., p. 153. 
Culturales, art. 6), hay que considerar como trabajo forzado, con el Convenio OIT sobre el trabajo forzoso de 1930 (CO29), "todo trabajo o servicio exigido a un individuo bajo la amenaza de una pena cualquiera y para el cual dicho individuo no se ofrece voluntariamente" (art. 2.1).

Por su parte, el art. 1.1 de la Convención sobre la Esclavitud, firmada en Ginebra el 25.09.1926, establece que esclavitud es "el estado o condición de un individuo sobre el cual se ejercitan los atributos del derecho de propiedad o algunos de ellos". En esta situación la persona esclavizada puede ser utilizada para la realización de diferentes actividades, con o sin contenido laboral.

El CP, a pesar de los nítidos mandatos internacionales, no criminaliza autónomamente la reducción a esclavitud o servidumbre, como tampoco lo hace con la imposición de trabajos forzados, aunque sí los considera objetivos que han de concurrir en el delito de trata de personas $(\mathrm{CP}$, art. 177 bis 1.a). Y, en aplicación del art. 7 del Estatuto de Roma de la Corte Penal Internacional, castiga como delito de lesa humanidad someter a alguna persona a esclavitud o mantenerla en ella, si los hechos se cometieren "como parte de un ataque generalizado o sistemático contra la población civil o contra una parte de ella". Por esclavitud se entenderá, precisa el CPE, "la situación de la persona sobre la que otro ejerce, incluso de hecho, todos o algunos de los atributos del derecho de propiedad, como comprarla, venderla, prestarla o darla en trueque "(art. 607 bis $)^{72}$.

Es dudoso, dado que nuestro ordenamiento no conoce los delitos de sometimiento a trabajo forzado o a condicio-

72 TERRADILLOS BASOCO, J.M., "Explotación laboral, trabajo forzoso, esclavitud. ¿Retos político-criminales para el siglo XXI?” cit., p. 237. 
nes de esclavitud o servidumbre ${ }^{73}$, que la fórmula legal del art. 177 bis permita incluir como modalidad de sometimiento a trabajos forzados la imposición de condiciones ilegales de trabajo del art. 311. Lo que provoca inevitables vacilaciones a la hora de enjuiciar.

Así, el TS, cuando afronta supuestos de hecho subsumibles en el concepto normativo internacional de servidumbre o esclavitud -"jornadas de trabajo de hasta 15 horas diarias, ausencia de descanso semanal, y de vacaciones, como también de retribución en caso de enfermedad, comidas y pernoctación en los propios talleres que carecían de las condiciones mínimas de seguridad y salud en el trabajo y donde estaban sometidos a estricto control en sus escasas salidas de los talleres" "74 - ha terminado condenando por un delito de explotación laboral del art. $312.2^{\circ}$, último inciso.

En otros casos, se ha condenado por un delito del art. 311 -sin más precisiones (!)- cuando las características de los hechos hubieran permitido también la consideración de sometimiento a servidumbre o esclavitud: los trabajadores "vivían en una parte de la paridera del ganado, compuesta por tres estancias, que sirven de dormitorios, sin agua corriente, ni sanitarios, ni cocina independiente, careciendo el recinto de las exigibles condiciones de higiene y salubridad, estando el recinto cuando fue visitado por la inspectora de trabajo con los suelos y accesorios sucios y con mal olor" ${ }^{75}$.

De esta suerte, la punición de las formas más graves de imposición ilegal de condiciones de trabajo queda confiada al art. 311 -nacido para afrontar formas mucho más livianas de

73 TERRADILLOS BASOCO, J.M., "Explotación laboral, trabajo forzoso, esclavitud. ¿Retos político-criminales para el siglo XXI?”, cit., p. 220.

74 STS, 2a, 17.05.2017, Antecedente de hechos. Primero y segundo (Ecli: ES:TS:2017:1908).

75 STS, 2a 28.09.2017, Antecedentes de hecho. Primero (Ecli: ES:TS:2017:3389). 
explotación- en concurso infraccional con los delitos de coacciones, injurias, contra la integridad moral, trata de personas con fines de explotación laboral o sexual, detenciones ilegales, etc., lo que permite llegar a marcos punitivos relativamente altos, pero desdibuja los perfiles propios de los gravísimos delitos de imposición de esclavitud o de trabajos forzados, invisibles, con las salvedades antedichas, para el legislador ${ }^{76}$.

La duda a resolver es, entonces, si la orientación de la trata de seres humanos a la ulterior explotación laboral, en los términos de los artículos $311.1^{\circ}$ y $4^{\circ}$ y 312.2 in fine puede integrar el delito de trata con la finalidad de imposición de trabajo o servicios forzados o condiciones similares a las de esclavitud o servidumbre.

La respuesta afirmativa vendría avalada por la inclusión de la explotación laboral entre los objetivos del delito de trata en la Resolución aprobada por el Consejo de Derechos Humanos en la Asamblea General de NU el 30 de junio de 2016. 32/3, que se refiere indistintamente a todas las formas de explotación, económica o laboral ${ }^{77}$. Y el Protocolo de Palermo ejemplifica que la explotación, para ser considerada objetivo típico del delito, ha de revestir las formas de trabajos o servicios forzados o de prácticas análogas a la esclavitud "como mínimo". Por lo tanto, como advierte el Proyecto de Ley modelo contra la trata de personas, elaborado en 2010 por la Oficina de NU contra la Droga y el Delito , "la lista no es exhaustiva". El mismo documento propone que la explotación típica debe incluir, entre otros objetivos tradicionalmente aceptados, "otras formas de explotación tipificadas en las leyes nacionales" (Art. 8.2.f).

76 TERRADILLOS BASOCO, J.M., "Explotación laboral, trabajo forzoso, esclavitud. ¿Retos político-criminales para el siglo XXI?”, cit., p. 237.

$77 \mathrm{http} / /$ www.acnur.org/fileadmin/scripts/doc.php?file=fileadmin/Documentos/BDL/2016/10894 
Queda a la decisión del legislador estatal el integrar expresamente en el tipo de trata la finalidad de imponer condiciones ilegales de trabajo que no lleguen al nivel de los trabajos forzosos o de la esclavitud. Y el legislador español no lo ha hecho, aunque esa vía no le está definitivamente cerrada al intérprete de la norma.

Una vez consumado el delito de trata de personas, la ulterior puesta en práctica de las finalidades típicas dará lugar a un concurso de delitos, tal como dispone expresamente el art. 177 bis 9 . Aunque la fórmula legal parece inclinarse por apreciar un concurso real, la vinculación teleológica entre la trata y el delito de explotación responde a la estructura del concurso medial. Así lo ha entendido la jurisprudencia ${ }^{78}$.

El legislador de 2010 previó la posibilidad de exigencia de responsabilidad penal a la persona jurídica (art. 177 bis 7), pero no a la mayoría de los delitos de explotación a los que la trata de seres humanos puede ir dirigida. De este modo, cabe que la persona jurídica responda por el delito de trata de personas con fines de explotación laboral de la gravedad que exige este delito (p. ej. en la modalidad de trabajos forzados), pero no por la propia explotación laboral, siendo así que la práctica evidencia que le presencia de personas jurídicas es más frecuente en las empresas que implementan la explotación que en las que organizan la trata.

\section{Responsabilidad de la empresa y responsabilidad de la persona jurídica}

La constancia de que los sujetos económicos actúan de ordinario bajo la forma de persona jurídica llevó a la LO 5/2010 a la introducción en nuestro sistema penal de la responsabilidad criminal de las personas jurídicas. Pero la

78 STS, 2a, 05.10.2017 Fundamentos de Derecho. Segundo (Ecli: ES:TS:2017:3565), 
ambiciosa reforma en la materia no llegó a los delitos contra los derechos de los trabajadores, "en los que lo habitual será, precisamente, la intervención de personas jurídicas"79. En este ámbito, a falta de previsión legal expresa -"en los supuestos previstos en este Código" dice el art. 31 bis para acotar su campo de aplicación-, sigue vigente el principio societas delinquere non potest.

De este modo, en los delitos contra derechos de los trabajadores atribuidos a personas jurídicas, estas no responderán penalmente, aunque sí es aplicable lo previsto en el art. 318 , objeto de una sustanciosa reforma por parte de la $L O$ 11/2003, que establece que "Cuando los hechos previstos en los artículos de este título se atribuyeran a personas jurídicas, se impondrá la pena señalada a los administradores o encargados del servicio que hayan sido responsables de los mismos y a quienes, conociéndolos y pudiendo remediarlo, no hubieran adoptado medidas para ello. En estos supuestos la autoridad judicial podrá decretar, además, alguna o algunas de las medidas previstas en el artículo 129 de este Código".

De este modo, cuando los hechos sean atribuibles a una persona jurídica, no entran en juego las reglas previstas para exigirle responsabilidad penal, señaladamente el art. 31 bis. En su lugar, el juzgador, además de depurar la responsabilidad de las personas físicas implicadas, podrá decretar, para aquella, alguna de las medidas del art. 129. Pero el art. 129 , cuya última modificación proviene de la $L O 1 / 2015$, no prevé medidas, sino "consecuencias accesorias a la pena que corresponda al autor [persona natural] del delito", que tendrán el contenido previsto en las letras c) a g) del apartado 7 del art. 33. Que es el precepto que recoge, precisamente, "las penas aplicable a las personas jurídicas".

79 RAMÓN RIBAS, E., "Delitos contra los derechos de los trabajadores: ¿responsabilidad penal de la empresa?”, en DE LA CUESTA AGUADO, P.M., et alii (coord.), Liber amicorum. Estudios jurídicos en Homenaje al Prof. Dr. Dr. H.c. Juan $\mathrm{M}^{\mathrm{a}}$ Terradillos Basoco, Tirant lo Blanch, Valencia, 2018, p. 993. 
Las sucesivas reformas legales, quizá no demasiado coordinadas, han determinado que, para un grupo de delitos en los que no es exigible responsabilidad penal a las personas jurídicas, se les termine imponiendo medidas/consecuencias accesorias de contenido idéntico al de las penas que en otros casos, cuando así esté expresamente previsto, corresponderían a las personas jurídicas ${ }^{80}$. El rodeo circular tiene una doble consecuencia: la previsión primera permite hacer responsable penalmente a la persona física no cualificada (el administrador no es empresario) de los delitos especiales del Título XV, en los que solo puede ser autor el empresario, cuando este es una persona jurídica ${ }^{81}$. La segunda regla solo puede conducir a dos opciones exegéticas, y ninguna satisfactoria: o no tiene aplicación ${ }^{82} \mathrm{o}$ es aplicable para castigar a las personas jurídicas con las penas previstas para ellas con carácter general, pero sin tener que fundamentar la condena en la concurrencia de requisitos exigidos por el art.31 bis, y con exclusión de los programas de cumplimiento, introducidos por la LO 1/2015.

\section{Bibliografía}

ACALE SÁNCHEZ, M., "Medidas de seguridad postpenitenciarias en el Código Penal Español: el movimiento de defensa social retro del siglo XXI", en Revista de Derecho Penal, 2013 (20), pp. 17-38.

AGUADO LÓPEZ, S., "Delitos contra los derechos de los trabajadores", en BOIX REIG, J. (dir.), LLORIA

80 FARALDO CABANA, C., El delito contra la seguridad e higiene en el trabajo, Tirant lo Blanch, Valencia, 2013, p. 246.

81 VILLACAMPA ESTIARTE, C., y SALAT PAISAL, M., "Título XV. De los delitos contra los derechos de los trabajadores", en QUINTERO OLIVARES, G., y MORALES PRATS, F. (dir.), Comentarios al Código Penal español, vol. 2, Aranzadi, Elcano, 2016, p. 736.

82 RAMÓN RIBAS, E., "Delitos contra los derechos de los trabajadores: ¿responsabilidad penal de la empresa?”, cit., pp. 995-997. 
GARCÍA, P. (coord.), Diccionario de Derecho Penal Económico, 2a ed., Iustel, Madrid, 2017, pp. 392-407.

BENÍTEZ ORTÚZAR, I.F., 2018, "A propósito de los nuevos artículos $311.2 \mathrm{CP}$ y 311 bis CP ¿Delitos contra los derechos de los trabajadores?, en DE LA CUESTA AGUADO, P.M., et alii (coord.), Liber amicorum. Estudios jurídicos en Homenaje al Prof. Dr. Dr. H.c. Juan $M^{a}$ Terradillos Basoco, Tirant lo Blanch, Valencia, 2018, pp. 1033-1047.

BAYLOS GRAU, A., y TERRADILLOS BASOCO, J.M., 2007, "Sobre el artículo 315 del Código Penal". http:// baylos.blogspot.com.es/2007/04/sobre-el-articulo3153-del-codigo-penal.html.

DE LA MATA BARRANCO, N.J., "Delitos contra la Hacienda Pública y la SS", en DE LA MATA BARRAN$\mathrm{CO}$ et alii, Derecho Penal Económico y de la Empresa, Dykinson, Madrid, 2018, pp. 529-592. https://doi. org/10.2307/j.ctv6gqx7s. 18

DE VICENTE MARTÍNEZ, R., “Se acabaron las mayorías parlamentarias! Una crónica política hacia la criminalización del ejercicio del derecho de huelga", en DE LA CUESTA AGUADO, P.M., et alii (coord.), Liber amicorum. Estudios jurídicos en Homenaje al Prof. Dr. Dr. H.c. Juan $M^{a}$ Terradillos Basoco, Tirant lo Blanch, Valencia, 2018, pp. 1066-1081.

DOLZ LAGO, M.J., "Los delitos contra la SS: entre la corrupción pública y la privada. Algunas claves frente al tsunami de la crisis económica y las quiebras del principio de igualdad", en Revista General de Derecho del Trabajo y de la SS, Madrid, 2014 (38). http://www.iustel.com/ v2/revistas/detalle_revista.asp?id $=12$ \&numero $=38$

DOLZ LAGO, M.J., , "Crisis económica y criminalización de los piquetes de huelga: claves para juristas", en La Ley, 23.10.2014, pp. 1-12. http://www.upfiscales.com/wp-content/uploads/2014/10/Dolz-Crisis-econo \%C3\%ACmicay-criminalizacio $\% \mathrm{C} 3 \% \mathrm{ACn}$-de-los-piquetes-de-huelgaDiario-La-Ley-23_10_2014-1.pdf 
DOLZ LAGO, M.J., “Existió alguna vez un verdadero Derecho penal del trabajo?", en DE LA CUESTA AGUADO, P.M., et alii (coord.), Liber amicorum. Estudios jurídicos en Homenaje al Prof. Dr. Dr. H.c. Juan $M^{a}$ Terradillos Basoco, Tirant lo Blanch, Valencia, 2018, pp. 964-977.

FARALDO CABANA, C., El delito contra la seguridad e higiene en el trabajo, Tirant lo Blanch, Valencia, 2013.

IGLESIAS RÍO, Miguel Á., "Delitos contra la Hacienda Pública y la SS", en ÁLVAREZ GARCÍA, Francisco Javier (dir.), Estudio crítico sobre el Anteproyecto de Reforma Penal de 2012, Tirant lo Blanch, Valencia, 2013, pp. 809-832.

LASCURAíN SÁNCHEZ, J.A., "Delitos contra los derechos de los trabajadores", en DE LA MATA BARRANCO, N., et alii, Derecho Penal Económico y de la Empresa, Dykinson, Madrid, 2018, pp. 593-628. https://doi.org/10.2307/j.ctv6gqx7s.19

LÓPEZ GARRIDO, D., y GARCÍA ARÁN, M., El Código Penal de 1995 y la voluntad del legislador, Eurojuris, Madrid, 1996.

MARTÍNEZ-BUJÁN PÉREZ, C., Derecho penal económico y de la Empresa, 5a ed., Tirant lo Blanch, Valencia, 2015. MÉNDEZ RODRÍGUEZ, C., "La técnica de tipificación y su relación con la aplicación de los delitos", en DE LA CUESTA AGUADO, P.M., et alii (coord.), Liber amicorum. Estudios jurídicos en Homenaje al Prof. Dr. Dr. H.c. Juan $M^{a}$ Terradillos Basoco, Tirant lo Blanch, Valencia, 2018, pp. 1095-1108.

NAVARRO CARDOSO, F., "El delito de contratación ilegal del art. 311 bis CP: un nuevo despropósito, y un viejo vicio, legislativo", en DE LA CUESTA AGUADO, P.M., et alii (coord.), Liber amicorum. Estudios jurídicos en Homenaje al Prof. Dr. Dr. H.c. Juan $M^{a}$ Terradillos Basoco, Tirant lo Blanch, Valencia, 2018, pp. 1049-1063. 
POMARES CINTAS, E., El Derecho Penal ante la explotación laboral y otras formas de violencia en el trabajo, Tirant lo Blanch, Valencia, 2013.

RAMÓN RIBAS, E., "Delitos contra los derechos de los trabajadores: ¿responsabilidad penal de la empresa?”, en DE LA CUESTA AGUADO, P.M., et alii (coord.), Liber amicorum. Estudios jurídicos en Homenaje al Prof. Dr. Dr. H.c. Juan $M^{a}$ Terradillos Basoco, Tirant lo Blanch, Valencia, 2018, pp. 991-1002

SÁEZ VALCÁRCEL, R., "Morir en el trabajo. Política criminal frente a los accidentes laborales", en SÁEZ VALCÁRCEL, R., (coord.), Siniestralidad laboral y Derecho penal, Consejo General del Poder Judicial, Madrid, 2006, pp. 37 a 106.

TAPIA BALLESTEROS, P., La discriminación laboral. Análisis del artículo 314 del Código penal, Tirant lo Blanch, Valencia, 2012.

TERRADILLOS BASOCO, J.M., "De la huelga como derecho al piquete como delito: a propósito de la sentencia sobre el caso 'los 8 de Airbus", en Revista de Derecho Social, 2016 (73), pp. 217-240.

TERRADILLOS BASOCO, J.M., "Delitos contra los derechos de los trabajadores", en TERRADILLOS BASOCO, J.M., (coord.), Derecho Penal. Parte Especial (Derecho Penal Económico), $2^{\mathrm{a}}$ ed., Iustel, Madrid, 2016, pp. 273-300.

TERRADILLOS BASOCO, J.M., "Explotación laboral, trabajo forzoso, esclavitud. ¿Retos político-criminales para el siglo XXI?", en DEMETRIO CASTRO, E., y NIETO MARTÍN, A. (dir.), Derecho penal Económico y Derechos Humanos, Tirant lo Blanch, Valencia, 2018, pp. 215-243.

TERRADILLOS BASOCO, J.M., 2019, "Centralidad del CP común versus dispersión en leyes penales sectoriales", en MEDINA CUENCA, A., (coord.), Perspectiva multidimensional del conflicto penal: de la política 
criminal a la concreción normativa "la línea invisible". Libro Homenaje a la profesora Dra. María Acale Sánchez, Unijuris, La Habana, 2019, pp. 19-47.

TERRADILLOS BASOCO, J. M., "Protección de los derechos económicos, sociales y culturales. Consideraciones político-criminales", en DEMETRIO CRESPO, E., (dir.), Derecho penal económico y teoría del delito, Tirant lo Blanch, Valencia, 2020, pp. 65-83.

TERRADILLOS BASOCO, J.M., y BOZA MARTÍNEZ, D., El Derecho penal aplicable a las relaciones laborales. Lecciones, Bomarzo, Albacete, 2017.

TERRADILLOS BASOCO, J.M., y BOZA MARTÍNEZ, D., "Fraude a la SS por elusión de pago de cuotas en la doctrina judicial. Sentencia 657/2017 del TS, Sala $2^{\text {a }}$, de lo Penal, de 05.10.2017”, en Revista de Derecho de la SS, 2018 (15), pp. 133-144. https://revista.laborum.es/index.php/revsegsoc/article/view/286

VIDALES RODRÍGUEZ, C., "Derecho penal del amigo. Reflexiones críticas acerca de la reciente modificación de los delitos contra la Hacienda Pública y la SS)", en Revista de derecho y proceso penal, 2013 (32), pp. 269-285.

VILLACAMPA ESTIARTE, C., y SALAT PAISAL, M., "Título XV. De los delitos contra los derechos de los trabajadores”, en QUINTERO OLIVARES, G., y MORALES PRATS, F. (dir.), Comentarios al Código Penal español, vol. 2, Aranzadi, Elcano, 2016, pp. 683-738. 